\title{
LONG-TERM CHANGES IN RIVER-FLOODPLAIN DYNAMICS: IMPLICATIONS FOR SALMONID HABITAT IN THE INTERIOR COLUMBIA BASIN, USA
}

\author{
by \\ Matthew James Tomlinson \\ B.Sc., The University of Michigan, 1999 \\ A THESIS SUBMITTED IN PARTIAL FULFILLMENT OF THE REQUIREMENTS FOR \\ THE DEGREE OF \\ MASTER OF SCIENCE \\ in \\ The Faculty of Graduate Studies \\ (Forestry) \\ THE UNIVERSITY OF BRITISH COLUMBIA \\ (Vancouver)
}

September 2009

(C) Matthew James Tomlinson, 2009 


\section{ABSTRACT}

Salmonids (salmon and trout) are threatened, endangered or at-risk throughout much of their historic range in western North America. However, a lack of detailed information about historic floodplain, riparian and channel condition makes it difficult to disentangle potential causes of population declines (e.g., habitat degradation vs. overfishing). For this research, historic habitat was reconstructed along five salmonid-bearing tributaries of the Columbia River using historic (1949) aerial photographs. Historic airphotos were scanned and orthorectified to create a $0.5 \mathrm{~m}$ resolution orthomosaic compatible with a USDA National Agricultural Imagery Program (NAIP) compressed county mosaic of modern (2006) imagery. Floodplain extent, land cover and stream reach type, as well as several types of floodplain and channel habitat important to salmonids, were delineated manually for both time periods. These features were compared between 1949 and 2006, across the five tributaries and at the reach level, using a combination of transition matrices, paired t-tests and ANOVAs. Quantifying these features helped provide historic and modern landscape-level indicators of floodplain, riparian and riverine condition.

The predominance of historic agriculture and contemporary urban expansion have likely reduced important salmonid habitat features in the Wenatchee system. Transitions of island braided channels to straight reaches were associated with significant reach shortening and increased anthropogenic modification to floodplain and riparian areas. When comparing the 1949 and 2006 landscapes, a loss of meandering reaches coincided with a reduction in the types of off-channel habitats associated with lateral channel migration (such as slow/stagnant and dry channels). Increased fragmentation of remaining habitat in highly modified river- 
floodplains may reduce the accessibility of contemporary floodplain habitat to salmonids. Unavoidable mapping error (due principally to solar glare) likely contributed to overestimating the historic predominance of straight reach types and an underestimate of island braided reaches.

This research provides an example of how anthropogenic activities may have contributed to declines in high quality salmonid habitat in the study area and can guide the prioritization of restoration efforts. The general methodology developed here can be adapted to other river floodplains throughout Canada and the USA where extensive anthropogenic modification may be of management concern. 


\section{TABLE OF CONTENTS}

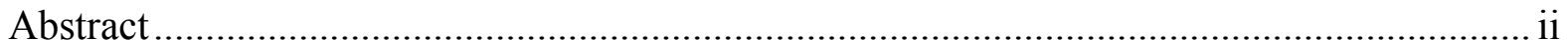

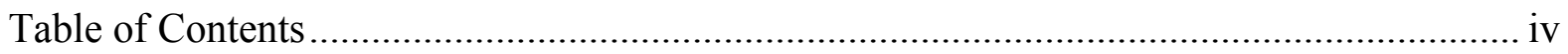

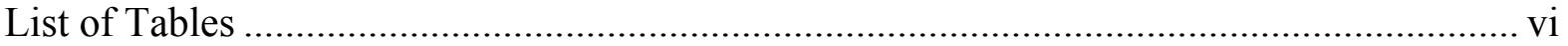

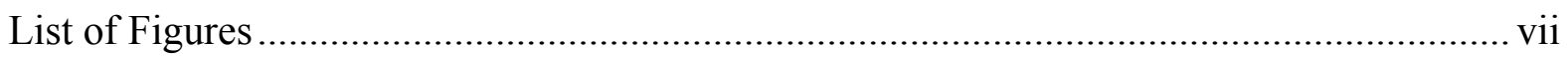

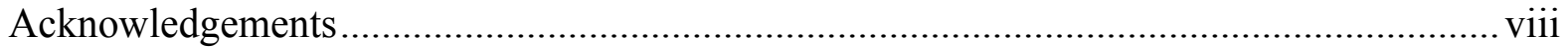

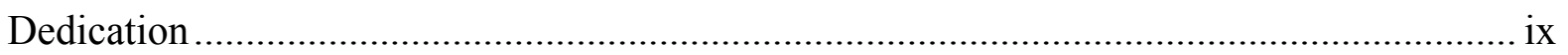

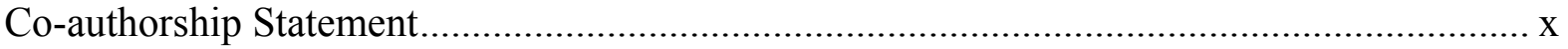

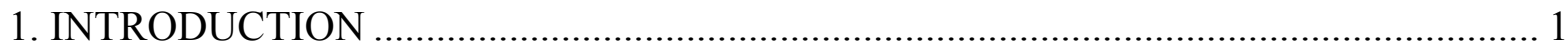

The Use of Landscape Indicators in Ecology ............................................................ 2

Orthorectification of Aerial Photographs.............................................................. 4

The Study Site and Salmonids ................................................................................... 5

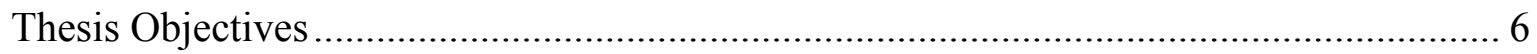

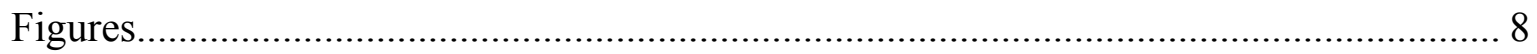

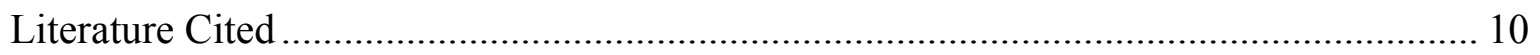

2. LONG-TERM CHANGES IN RIVER-FLOODPLAIN DYNAMICS: IMPLICATIONS

FOR SALMONID HABITAT IN THE INTERIOR COLUMBIA BASIN, USA ................ 13

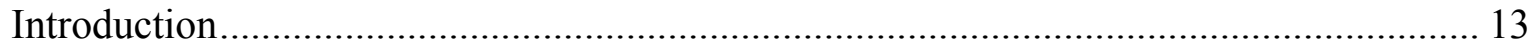

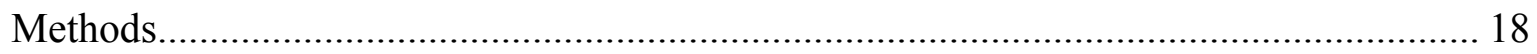

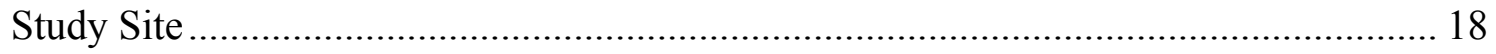

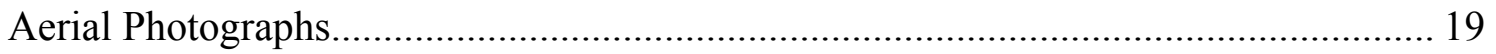

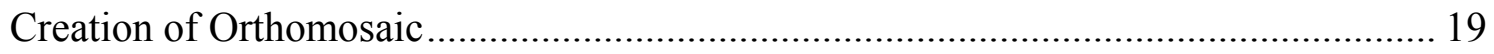

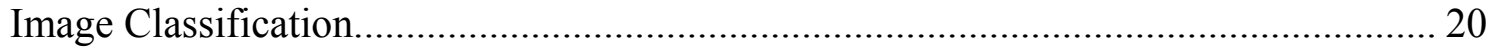


Change Detection and Statistical Analyses....................................................... 23

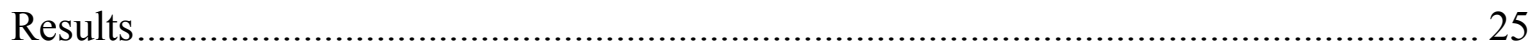

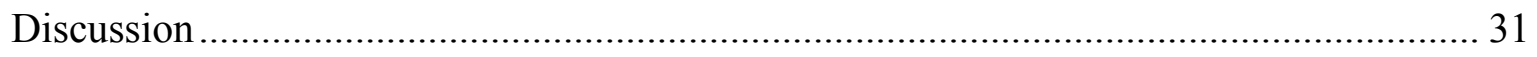

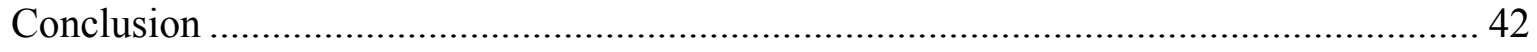

Implications for Salmonids ............................................................................ 42

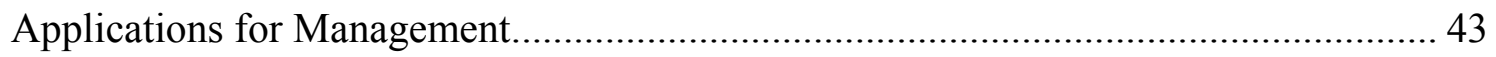

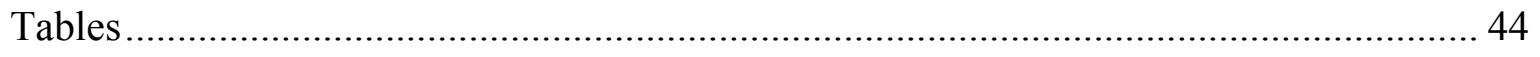

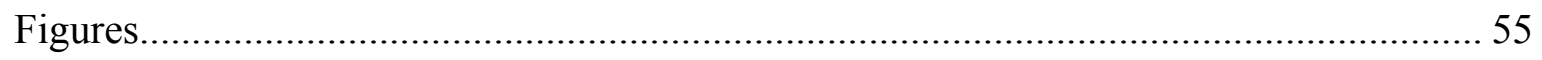

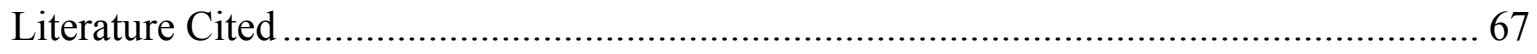

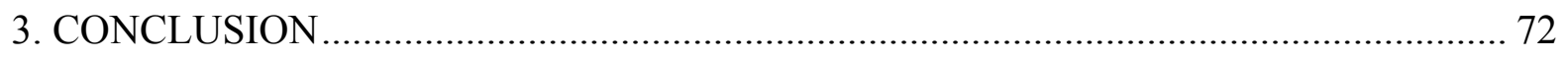

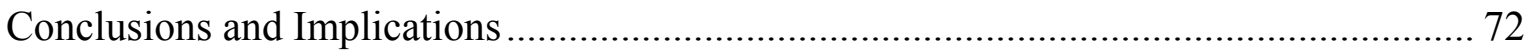

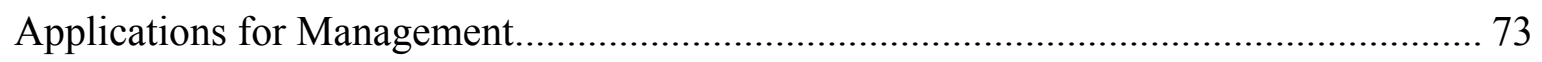

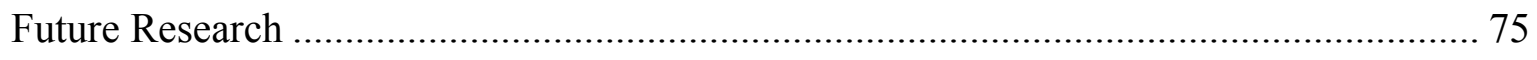

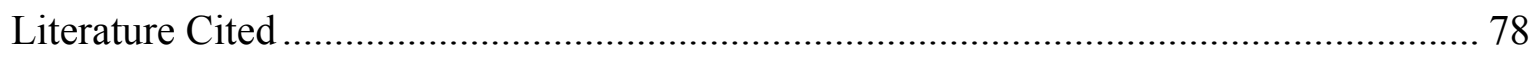

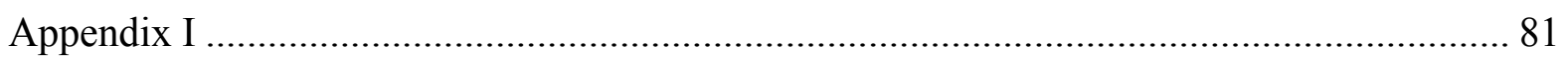

Orthorectification of Aerial Photographs.......................................................... 81

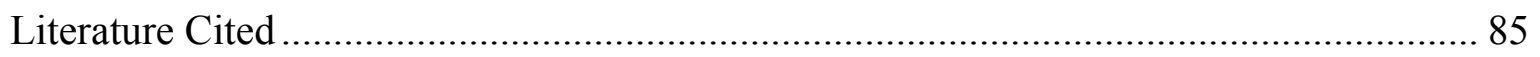




\section{LIST OF TABLES}

Table 2-1: Description of broad-scale (A) and fine-scale (B - C) classification schemes mapped in this study, as well as identifying characteristics and scales used for digitization. 44

Table 2-2: Transition matrices showing land cover change from 1949 to 2006 at 3000 randomly generated points: (A) Raw tally matrix of instances of change, (B) Probability matrix $(0.0-1.0)$.

Table 2-3: Accuracy assessment of the general land cover mapped on modern orthoimagery. Raw tally confusion matrix of land cover and calculated accuracies of the classification scheme are provided. Agreement is shown along the diagonal (in bold) and discrepancies are shown in off-diagonals. Overall accuracy denoted with $(*)$; kappa coefficient $=0.8 \ldots . .48$

Table 2-4: Changes in reach type for all reaches $(\mathrm{N}=424)$ in the Wenatchee system from 1949 to 2006: (A) Raw tally matrix of instances of change, (B) Probability matrix (0.0 - 1.0). Dynamics of transitioning reaches (in bold) are examined further in Table 5.

Table 2-5: Comparison of mean characteristics in transitioning reaches (identified in Table 4) compared to reaches which remained unchanged from 1949 to 2006 (A - C). Differences between 1949 and 2006 mean values as well as the change over time have also been compared. Significant $\mathrm{p}$-values have been highlighted (in bold).

Table 2-6: Changes in mean area and number of habitat features at the reach level. Reaches were included only if they contained a given habitat feature in one or both years. Significant change highlighted in bold.

Table 2-7: Comparison of mean area and mean number of floodplain and channel habitat features for floodplains with (A) higher and (B) lower anthropogenic modification to the floodplain (as described in Figure 6). Significant change highlighted in bold. 


\section{LIST OF FIGURES}

Figure 1.1: The Wenatchee River Watershed, WA, USA. Nearby watersheds where similar research on salmonid habitat has been conducted are noted and referred to further in Chapter Two.

Figure 1.2 : Examples of unconfined (streams with intact floodplains) reach types found in the Wenatchee System. Images adapted from Beechie et al. (2006).....

Figure 2.1: The Wenatchee River Watershed, Washington, USA.................................... 55

Figure 2.2: Monthly median historic (1949) and modern (2006) stream discharge as well as median monthly discharge and range (maximum and minimum discharge) spanning 1929 2007 for of the Wenatchee River below Leavenworth, WA (Figure 1). Modern orthophotos acquired in July - August 2006; historic imagery acquired September 3 - 21, 1949 .......... 56

Figure 2.3: A comparison of coarse and fine scale landscape views. (A) Coarse scale showing general land cover (agriculture, urban forest/shrub and road). (B) Fine scale showing floodplain habitat features (e.g., slow/stagnant channels).

Figure 2.4: (A) A subsample of the GPS points used to assess the accuracy of the modern general land cover classification scheme in a confusion matrix (Table 3). (B) A subsample of the 3,000 randomly generated points used to create the transition matrix (Table 2) of the general land cover classification scheme.

Figure 2.5: Changes in general land cover types within (A) floodplain and (B) riparian area of the Wenatchee system (Wenatchee, Chiwawa, White and Little Wenatchee Rivers and Nason Creek).

Figure 2.6: Percent of (A) floodplain and (B) riparian area modified by anthropogenic development (i.e., urban, agriculture and roads) for the Wenatchee system. Data from 1949 displayed in the left column and 2006 in the right column for each pairing.

Figure 2.7: Changes in relative abundance of different reach types for all 424 reaches within in the Wenatchee system.

Figure 2.8: Changes in (A) total area and (B) number of floodplain and channel habitat features observed within the Wenatchee system. Percent change over time displayed above each set of paired bars.

Figure 2.9: Impact of floodplain land cover modification (i.e., agriculture, urban and roads) on total (A) area and (B) number of floodplain and channel habitat features from 1949 to 2006. As shown in Figure 6, Wenatchee River and Nason Creek represent rivers with highly modified floodplains, whereas Chiwawa, White and Little Wenatchee Rivers represent rivers with less modified floodplains. 


\section{ACKNOWLEDGEMENTS}

This research was funded by grants from the National Oceanic and Atmospheric Administration National Marine Fisheries Service (NOAA Fisheries, USA); the Natural Sciences and Engineering Research Council (NSERC) of Canada; and Environment Canada - Environmental Damages Fund to Dr. Sarah Gergel. Additional support provided by The Nature Trust of British Columbia Bert Hoffmeister Scholarship and the Donald McPhee Fellowship provided to myself.

I am indebted to Dr. Sarah Gergel for her time, feedback and constant support throughout my tenure as a student. I am also grateful for the support from my committee - Dr. Nicholas Coops, Dr. Scott Hinch and Dr. Michelle McClure - who made it perfectly clear they always had the time to answer my questions, no matter how inane. Further appreciation is extended to Dr. Timothy Beechie whose help developing the methods of this project and teaching me the ways of fluvial geomorphology from 20,000 feet was invaluable. Special thanks to Collin Ankerson are in order; without your dedicated work (and occasional distractions for movie gossip), I would not have finished in this decade.

Thank you to my lab and lab-adoptees - Jessica Morgan, Trevor Lantz, Shanley Thompson, Kate Kirby, Hélène Marcoux, Hilary Thorpe, Chris Bater, Trevor Jones, Sam Coggins - for fielding ridiculous questions and helping solve all of the wonderful problems associated with daily life. I am truly indebted to you fine folks!

Finally, a special thank you to my wife - Alaine Camfield - without you, I would have been a train wreck. 


\section{DEDICATION}

to a little bird who whispered in my ear, "you can do this." 


\section{CO-AUTHORSHIP STATEMENT}

This thesis will compose one scientific manuscript for which I am the lead author. I performed all research, data analysis, interpretation of results and prepared the final manuscript. The initial project structure was developed by Dr. Sarah Gergel and Dr. Michelle McClure who identified the study site and elucidated the main objectives. I orthorectified the historic images and created the final orthomosaic. Digitizing of the datasets used in subsequent analyses was completed by myself and Collin Ankerson. Dr. Sarah Gergel provided valuable insight on methods, results and discussion as well as feedback on the scientific writing process. Dr. Timothy Beechie also provided significant comments on methods, results and discussion. 


\section{INTRODUCTION}

Current rates of species extinction are thousands of times higher than background levels and are occurring in a catastrophically short time interval (Novacek and Cleland 2001). The predominant cause of species endangerment is habitat loss and degradation (Pimm and Raven 2000). Although large tracts of unaltered habitat remain worldwide, most of the planet's natural ecosystems have been modified or fragmented (Pimm et al. 2006). Aquatic environments are no exception as $77 \%$ of the largest rivers in North America (north of Mexico) and Eurasia having been moderately to strongly affected by fragmentation from dams and water regulation (Dynesius and Nilsson 1994). With massive degradation of aquatic ecosystems, fish population declines are to be expected. Williams et al. (1989) updated the list of rare North American inland fishes; 139 new taxa were added totaling 364 fishes in Canada, the United States and Mexico that warranted protection due to rarity. Not a single species was removed from the original list due to recovery efforts (Williams et al. 1989).

Salmonids (salmon and trout) are threatened, endangered or at-risk throughout much of their historic range in western North America (Nehlsen et al. 1991, NRC 1996, Myers et al. 1998, Schindler et al. 2003). As an addendum to the report by Williams et al. (1989), the American Fisheries Society created a list of depleted Pacific salmon, steelhead and sea-run cutthroat stocks. The list included 214 native naturally-spawning stocks: 101 at high risk of extinction, 58 at moderate risk of extinction, 54 of special concern and one classified as threatened under the Endangered Species Act (Nehlsen et al. 1991). Habitat degradation, overfishing and 
other anthropogenic influences are largely responsible for salmonid population declines (Nehlsen et al. 1991, Beechie et al. 1994).

The terrestrial environment has a substantial impact on stream ecosystems and therefore anthropogenic modification of floodplain and riparian areas is of paramount importance to salmonid conservation (Murphy and Meehan 1991, Naiman et al. 2000). Riparian areas are a source of large wood (a critical factor in shaping channel morphology) and provide nutrients to streams, regulate stream temperature, retain organic matter and stabilize and maintain undercut stream banks (Murphy and Meehan 1991). Floodplain channels provide important over-winter habitat for salmonids and are a source of macroinvertebrates when channels are connected (Collins et al. 2002, Hohensinner et al. 2004). In some cases, juvenile salmonids reared in floodplain channels had higher growth rates than those that remained in the main stem (Sommer et al. 2001, Jeffres et al. 2008). Therefore, an understanding of historic and modern distribution and relative abundances of floodplain land cover and habitat as well as channel form is an important component in quantifying changes in salmonid habitat quality and availability over time.

\section{The Use of Landscape Indicators in Ecology}

It can often be difficult to ask questions at broad spatial scales when using the traditional empirical approaches of field-based studies in ecology. A lack of funding, time availability, adequate numbers of properly trained personnel, access to study sites, etc., all contribute to this difficulty. Moreover, conducting research over long time scales or addressing historical ecological questions further complicates matters. This is not to imply that traditional 
ecological studies have not been conducted at large spatial scales or over long periods of time (Symstad et al. 2003), but rather, the complexity of successfully completing such studies often limits their numbers. Landscape ecology, however, has developed tools to accomplish such tasks while bypassing some of these limitations.

Landscape indicators are often used to quantify how a change in landscape pattern (e.g., land cover or stream type) has affected some ecological process (e.g., sedimentation rates into a stream; Gergel et al. 2002). Landscape indicators are measurements of land cover, land use or other landscape-level variable that can serve as a proxy for a specific ecological attribute. For example, Sponseller et al. (2001) used measures of riparian forest cover to predict instream macroinvertebrate densities. Furthermore, increases in impervious surface (i.e., urbanization) change a stream's hydrologic regime and channel morphology (White and Greer 2006). Landscape indicators, such as measurements of riparian forest cover or percent impervious surface, are useful because they are easily quantified in a digital environment and, subsequently, can cover broad spatial scales.

Landscape indicators can also be used to analyze the historic dynamics of ecosystems. Contemporary plant species diversity was largely a legacy of historic land cover (Lindborg and Eriksson 2004), and Cubizolle et al. (2003) provided evidence that current plant diversity was influenced by human activity from hundreds of years prior. Harding et al. (1998) showed that historic land cover was a better predictor of stream biodiversity than modern land cover. Despite the fact that the historic landscape pattern has a large influence on a diversity of ecological processes, very little work has been conducted to develop historic 
indicators (Gergel et al. 2002, Poudevigne and Baudry 2003). Thus, while many studies have made the connection between land cover and ecological function (Klein 1979, Roth et al. 1996, Wang et al. 1997), a critical next step is to develop rigorous techniques for historic landscape indicators. This study uses landscape indicators (e.g., percent floodplain modification, area of off-channel habitat, etc.) to infer changes in the abundance and quality of salmonid habitat using contemporary and historically reconstructed data. Historic aerial photographs were used to provide much of this information.

\section{Orthorectification of Aerial Photographs}

While historic photos are a valuable resource, the inherent errors associated with the photography must first be corrected before analysis can proceed. The historic data used in this study were collected from a mosaic of historic aerial photographs (circa 1949). The airphotos were first orthorectified before any measurements were taken. As an aerial photograph is captured, a number of distortions or degradations (e.g., relief/tilt distortion or radial displacement) are manifested in the resultant image. Orthorectification is the process of correcting these errors and creating an orthophoto that is free of distortions and has a constant scale. The resultant image is considered to be planimetrically correct. After the image has been rectified, it can be used to extract accurate distances, calculate areal measurements, record direction or relate data in a geographic information system (GIS). Orthorectification is further discussed in the methods section of Chapter Two; a detailed account of the orthorectification workflow is found in Appendix I. 


\section{The Study Site and Salmonids}

The Columbia River is the largest river in the Pacific Northwest region of North America, spanning seven states (Washington, Oregon, Idaho, Montana, Nevada, Utah and Wyoming) and one Canadian province (British Columbia). The river is approximately 2,000 km long and drains approximately $668,000 \mathrm{~km}^{2}$, with an average discharge at the mouth of 7,500 $\mathrm{m}^{3} / \mathrm{s}$. The Columbia River basin is also the most hydroelectrically developed river system in the world with over 400 dams, 14 of which span the Columbia main stem. Some of these dams employ fish ladders, to varying degrees of success, to allow the numerous species of anadromous salmonids native to the Columbia to migrate to their natal grounds. The Chief Joseph and Grand Coulee dams, the tenth and eleventh dams on the Columbia, have no fish bypass systems in place and thus block fish migration completely.

The study area consists of the Wenatchee River and four of its main salmonid-bearing tributaries (Chiwawa, Little Wenatchee and White Rivers and Nason Creek). The mouth of Wenatchee River is approximately $750 \mathrm{~km}$ upstream of the confluence of the Columbia and the Pacific Ocean, a section of river containing seven dams as of 1971. These five streams are located in central Washington State in Chelan County (Figure 1) and are referred to collectively as the Wenatchee system. Other streams in adjacent river basins have been the subject of similar research and are used as the basis for comparisons discussed in Chapter Two (Figure 1). Further detail about the Wenatchee basin (such as land cover, ecology and geology) is provided in the methods of Chapter Two as well as in Jorgensen et al. (2009). 
The Wenatchee basin now contains two endangered evolutionary significant units of salmonids, Upper Columbia River spring-run Chinook salmon (Oncorhynchus tshawytscha) and Upper Columbia River steelhead (O. mykiss). Coho salmon (O. kisutch) have been extirpated from this watershed. Chinook salmon are anadromous; they spend most of their lives in the ocean and return to freshwater to spawn. Spring Chinook salmon return to freshwater in spring and deposit eggs in late summer or autumn. The eggs hatch in the subsequent spring and juveniles overwinter in the catchment before migrating to the ocean the following spring (Jorgensen et al. 2009). The fish remain in the ocean for one to three years before completing their lifecycle by returning to their natal grounds to spawn. Chinook salmon are semelparous (spawn once per lifetime); both males and females die after spawning. Females defend the redd (an excavated nest on the stream bottom containing the eggs) for short duration of time after mating while males continue to search for additional mating opportunities before dying. The average lifespan of a Chinook salmon is three to five years.

\section{Thesis Objectives}

The overall objective of this study was to quantify changes in land cover, channel form and floodplain habitat along the Wenatchee River and four of its major tributaries in Washington, USA and relate these changes to changes in the quality of salmonid habitat. Three research questions were addressed: (1) What was the historic distribution and relative abundance of land cover in the floodplain and riparian zone and how has this changed through time; (2) What were the original abundances of historic stream reach types and how have they changed through time; and (3) What was the historic distribution and relative abundance of floodplain 
and channel habitat and how has this changed through time? In answering these questions, inferences can be made as to how salmonid habitat has changed over time and how anthropogenic modification activities may have contributed to those changes. Furthermore, the benefits and limitations of these types of historic landscape indicators can be explored. Finally, implications for salmonids and applications for management are explored based on the observed changes in land cover, stream reach type and floodplain and channel habitat from this study. 


\section{Figures}

Figure 1.1: The Wenatchee River Watershed, WA, USA. Nearby watersheds where similar research on salmonid habitat has been conducted are noted and referred to further in Chapter Two.

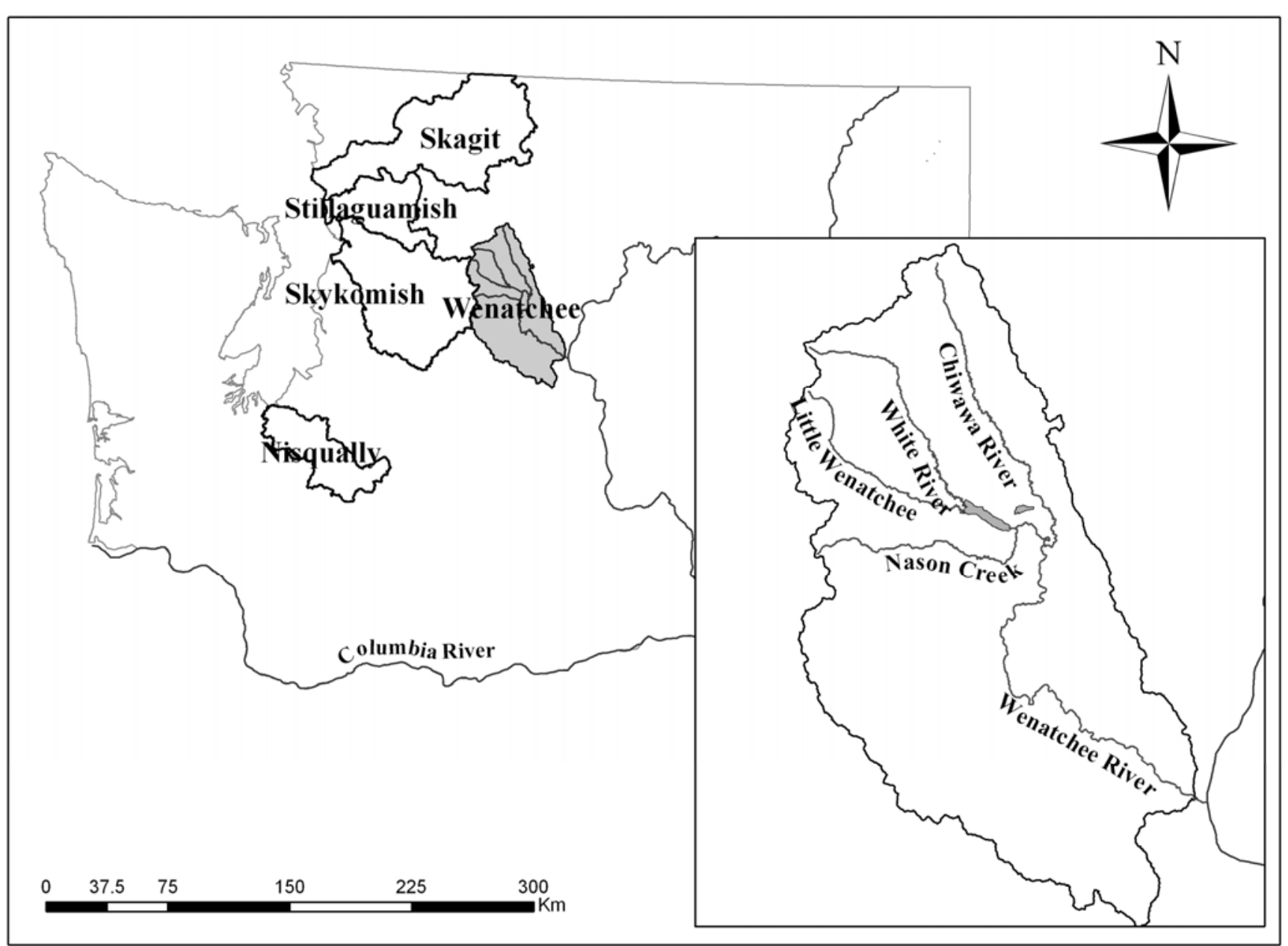


Figure 1.2 : Examples of unconfined (streams with intact floodplains) reach types found in the Wenatchee System. Images adapted from Beechie et al. (2006).
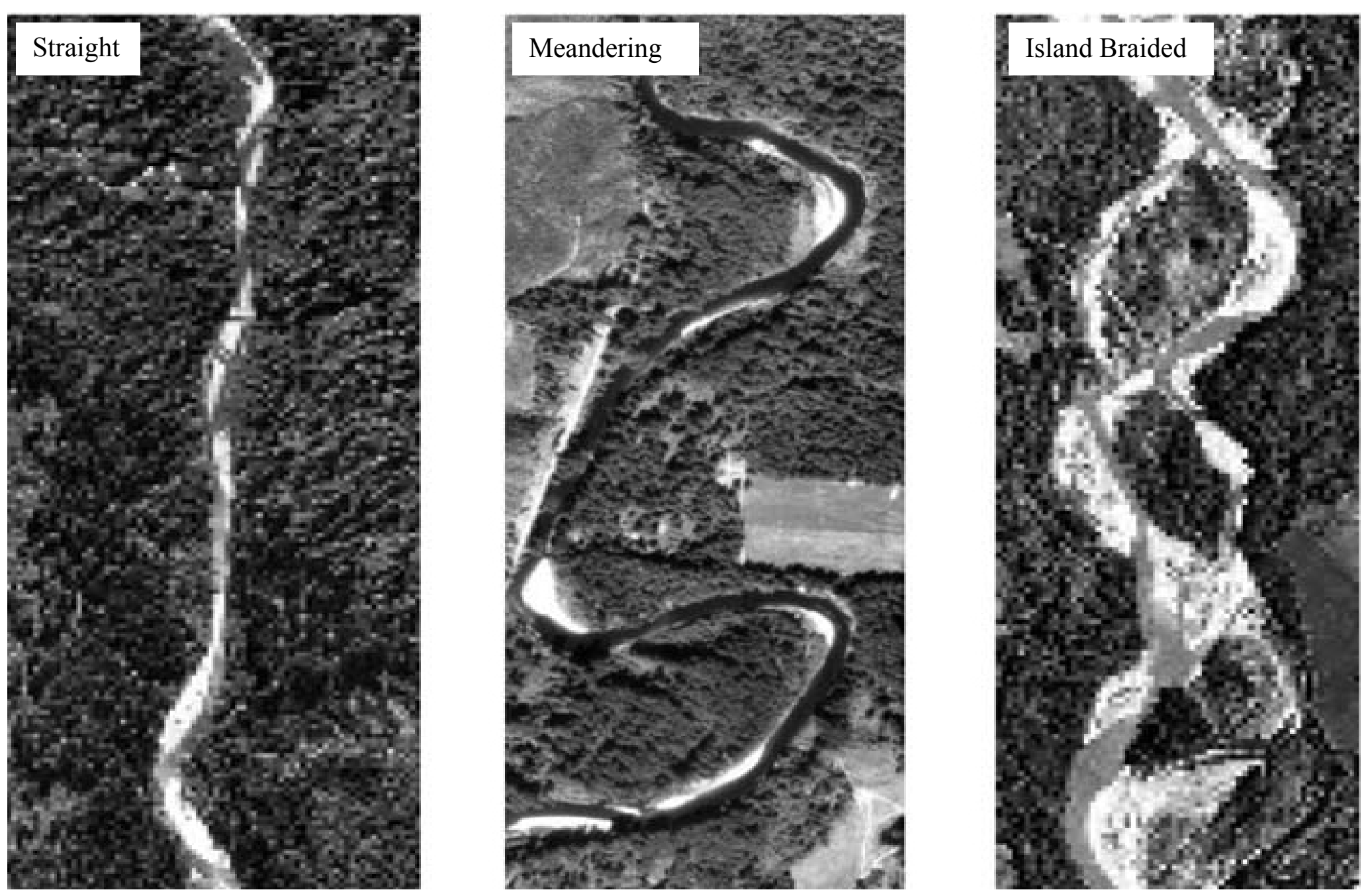


\section{Literature Cited}

Beechie, T. J., E. Beamer, and L. Wasserman. 1994. Estimating Coho Salmon Rearing Habitat and Smolt Production Losses in a Large River Basin, and Implications for Habitat Restoration. North American Journal of Fisheries Management 14:797-811.

Beechie, T. J., M. Liermann, M. M. Pollock, S. Baker, and J. Davies. 2006. Channel pattern and river-floodplain dynamics in forested mountain river systems. Geomorphology 78:124-141.

Collins, B. D., D. R. Montgomery, and A. D. Haas. 2002. Historical changes in the distribution and functions of large wood in Puget Lowland rivers. Canadian Journal of Fisheries and Aquatic Sciences 59:66-76.

Cubizolle, H., A. Tourman, J. Argant, J. Porteret, C. Oberlin, and K. Serieyssol. 2003. Origins of European biodiversity: palaeo-geographic signification of peat inception during the Holocene in the granitic eastern Massif Central (France). Landscape Ecology 18:227-238.

Dynesius, M. and C. Nilsson. 1994. Fragmentation and Flow Regulation of River Systems in the Northern 3rd of the World. Science 266:753-762.

Gergel, S. E., M. G. Turner, J. R. Miller, J. M. Melack, and E. H. Stanley. 2002. Landscape indicators of human impacts to riverine systems. Aquatic Sciences 64:118-128.

Hohensinner, S., H. Habersack, M. Jungwirth, and G. Zauner. 2004. Reconstruction of the characteristics of a natural alluvial river-floodplain system and hydromorphological changes following human modifications: The Danube River (1812-1991). River Research and Applications 20:25-41.

Jeffres, C. A., J. J. Opperman, and P. B. Moyle. 2008. Ephemeral floodplain habitats provide best growth conditions for juvenile Chinook salmon in a California river. Environmental Biology of Fishes 83:449-458.

Jorgensen, J. C., J. M. Honea, M. M. McClure, T. D. Cooney, K. Engie, and D. M. Holzer. 2009. Linking landscape-level change to habitat quality: an evaluation of restoration actions on the freshwater habitat of spring-run Chinook salmon. Freshwater Biology 54:1560-1575.

Klein, R. D. 1979. Urbanization and Stream Quality Impairment. Water Resources Bulletin 15:948-963.

Lindborg, R. and O. Eriksson. 2004. Historical landscape connectivity affects present plant species diversity. Ecology 85:1840-1845. 
Murphy, M. L. and W. Meehan. 1991. Stream Ecosystems. Pages 17-46 in W. Meehan, editor. Influences of Forest and Rangeland Management on Salmonid Fisheries and Their Habitats. American Fisheries Society Special Publication, Bethesda, Maryland.

Myers, J. M., R. G. Kope, G. J. Bryant, D. Teel, L. J. Lierheimer, T. C. Wainwright, W. S. Grant, F. W. Waknitz, K. Neely, S. T. Lindley, and R. S. Waples. 1998. Status review of chinook salmon from Washington, Idaho, Oregon, and California., U.S. Department of Commerce.

Naiman, R. J., R. E. Bilby, and P. A. Bisson. 2000. Riparian ecology and management in the Pacific Coastal Rain Forest. Bioscience 50:996-1011.

Nehlsen, W., J. E. Williams, and J. A. Lichatowich. 1991. Pacific Salmon at the Crossroads Stocks at Risk from California, Oregon, Idaho, and Washington. Fisheries 16:4-21.

Novacek, M. J. and E. E. Cleland. 2001. The current biodiversity extinction event: Scenarios for mitigation and recovery. Proceedings of the National Academy of Sciences of the United States of America 98:5466-5470.

NRC. 1996. Upstream : salmon and society in the Pacific Northwest. National Academy Press, Washington, D.C.

Pimm, S., P. Raven, A. Peterson, C. H. Sekercioglu, and P. R. Ehrlich. 2006. Human impacts on the rates of recent, present, and future bird extinctions. Proceedings of the National Academy of Sciences of the United States of America 103:10941-10946.

Pimm, S. L. and P. Raven. 2000. Biodiversity - Extinction by numbers. Nature 403:843-845.

Poudevigne, I. and J. Baudry. 2003. The implication of past and present landscape patterns for biodiversity research: introduction and overview. Landscape Ecology 18:223-225.

Roth, N. E., J. D. Allan, and D. L. Erickson. 1996. Landscape influences on stream biotic integrity assessed at multiple spatial scales. Landscape Ecology 11:141-156.

Schindler, D. E., M. D. Scheuerell, J. W. Moore, S. M. Gende, T. B. Francis, and W. J. Palen. 2003. Pacific salmon and the ecology of coastal ecosystems. Frontiers in Ecology and the Environment 1:31-37.

Sommer, T. R., M. L. Nobriga, W. C. Harrell, W. Batham, and W. J. Kimmerer. 2001. Floodplain rearing of juvenile chinook salmon: evidence of enhanced growth and survival. Canadian Journal of Fisheries and Aquatic Sciences 58:325-333.

Symstad, A. J., F. S. Chapin, D. H. Wall, K. L. Gross, L. F. Huenneke, G. G. Mittelbach, D. P. C. Peters, and D. Tilman. 2003. Long-term and large-scale perspectives on the relationship between biodiversity and ecosystem functioning. Bioscience 53:89-98. 
Wang, L. Z., J. Lyons, P. Kanehl, and R. Gatti. 1997. Influences of watershed land use on habitat quality and biotic integrity in Wisconsin streams. Fisheries 22:6-12.

White, M. D. and K. A. Greer. 2006. The effects of watershed urbanization on the stream hydrology and riparian vegetation of Los Penasquitos Creek, California. Landscape and Urban Planning 74:125-138.

Williams, J. E., J. E. Johnson, D. A. Hendrickson, S. Contreras-Balderas, J. D. Williams, M. Navarro-Mendoza, D. E. McAllister, and J. E. Deacon. 1989. Fishes of North America Endangered, Threatened, or of Special Concern: 1989. Fisheries 14:2-20. 


\section{LONG-TERM CHANGES IN RIVER-FLOODPLAIN DYNAMICS: IMPLICATIONS FOR SALMONID HABITAT IN THE INTERIOR COLUMBIA BASIN, USA ${ }^{1}$}

\section{Introduction}

Salmonids (salmon and trout) are threatened, endangered or at-risk throughout much of their historic range in western North America (Nehlsen et al. 1991, NRC 1996, Myers et al. 1998, Schindler et al. 2003). Habitat degradation, overfishing and other anthropogenic influences are largely responsible for salmonid population declines (Nehlsen et al. 1991, Beechie et al. 1994). The Columbia basin, which drains portions of British Columbia and several US states, represents some of the most important salmonid habitat in the Pacific Northwest. Currently, three populations of salmon in British Columbia are designated as endangered by the Committee on the Status of Endangered Wildlife in Canada (DFO 2005) and seven salmonid populations in the Interior Columbia River are listed as either threatened or endangered under the US Endangered Species Act (ICTRT 2003). The health and long-term viability of salmonids in western Canada is inextricably linked to the availability of productive habitat (DFO 2005). At present, a lack of data on historical land cover and riparian and channel condition makes it difficult to disentangle potential causes of population declines.

\footnotetext{
${ }^{1}$ A version of this chapter will be submitted for publication. Tomlinson, M.J., Gergel, S.E., Beechie, T.E., and McClure, M.M. Long-Term Changes in River-Floodplain Dynamics: Implications for Salmonid Habitat in the Interior Columbia Basin, USA.
} 
Landscape indicators (i.e., measurements of the landscape that serve as a proxy for a specific ecological attribute) are routinely used to elucidate the connections between terrestrial and aquatic ecosystems at multiple scales (Innis et al. 2000, Gergel et al. 2002b). For example, upland watershed land use practices (i.e., urbanization) have been directly linked to increased median and minimum stream discharge, flood magnitude and changes in channel geomorphology (White and Greer 2006) and percent of riparian non-forested area directly affects in-stream macroinvertebrate densities (Sponseller et al. 2001). Relationships such as these provide insights as to how changes in landscape variables can serve as proxies for specific riverine conditions (Gergel et al. 2002b). Interestingly, very little work has been conducted developing historic landscape indicators for riverine systems despite the fact that historic landscape pattern has a great effect on a diversity of ecological processes (Gergel et al. 2002b, Poudevigne and Baudry 2003, Lindborg and Eriksson 2004). For example, in streams, Harding et al. (1998) found that in currently forested areas, historic land cover data was a better predictor of stream biodiversity than was the present land cover data.

Due to the clear importance of past changes in land cover affecting current ecosystem condition, a combination of historic and modern orthoimagery was used to quantify changes in land cover, stream reach type and floodplain and channel habitat within the floodplain of the study area over time, serving as landscape indicators of changes in riverine and fish habitat condition. The oldest available complete set of historic aerial photographs (circa 1949) for the Wenatchee River watershed was orthorectified and mosaiced; equivalent modern orthoimagery (circa 2006) was obtained from the National Agriculture Imagery Program. Historic and modern land cover, floodplain features and channel habitat were 
manually digitized, and changes in stream reach types were determined to address three major questions:

1. What was the historic distribution and relative abundance of land cover in the floodplain and riparian zone, and how has this changed through time?

Anthropogenic alterations to river-floodplain ecosystems (e.g., hydroelectric power plants) greatly affect ecosystem function and have led to declines in fish species worldwide (Jungwirth et al. 2002). For example, 50\% of coho salmon (Oncorhynchus kisutch) winter habitat in watersheds adjacent to the Wenatchee system have been destroyed by human alteration to the floodplains and deltas (Beechie et al. 2001). Forested land cover reduces surface runoff, maintains stable stream temperature and flow regimes and is a source of large wood providing food and habitat for in-stream organisms; agricultural land cover is found to have the opposite effect on streams (Wang et al. 1997). As a result, percent agricultural and forested area in a watershed is often used as an indicator of stream condition. Therefore, a basic classification of historic and modern land cover (agriculture, forest, urban and road) was developed to provide information on the river-floodplain ecosystem condition.

Furthermore, vegetation in riparian areas affects the physical habitat and processes within and alongside streams (Meehan et al. 1977, Bjornn and Reisser 1991, Gregory et al. 1991, Pollock 1998, Naiman et al. 2000) and thus directly affects salmonid survival (Meehan et al. 1977, Bjornn and Reisser 1991, Murphy and Meehan 1991, Fausch and Northcote 1992). Riparian vegetation directly affects stream temperature by blocking direct solar radiation to the stream. As salmonids have specific temperature requirements (Bjornn and Reisser 1991), 
changes in bank-side vegetation can have significant consequences on fish populations (Murphy and Meehan 1991). Riparian vegetation is also a substantial source for allochthonous nutrient inputs upon which streams are dependent (Murphy and Meehan 1991). Thus, quantifying percent forested land cover in riparian areas, and how this may have changed over time, can help provide an indication where these important processes may have undergone the greatest change.

2. What were the original abundances of historic stream reach types, and how have they changed through time?

Specific habitat requirements vary greatly among salmonids (Bjornn and Reisser 1991, Hicks et al. 1991) and during different life stages. Some of these important habitats are associated with different fluvial-geomorphic reach types. For example, the preferred rearing habitat for coho salmon (O. kisutch) includes stream pools, whereas steelhead (O. mykiss) prefer riffle habitat (Bugert et al. 1991, Young 2001). Furthermore, channel confinement and gradient greatly influence spawning and rearing habitat potential; for example, as channel confinement and gradient increases, spawning habitat decreases (ICTRT 2007). Moreover, specific types of unconfined channels (e.g., meandering and island braided) are more biologically diverse (Beechie et al. 2006, Zanoni et al. 2008) and thought to produce and maintain higher quality salmonid habitat than less complex, unconfined channels (e.g., straight). For these reasons, qualitative data describing stream reach type is a potentially important indicator of salmonid habitat suitability. Thus, stream reaches in 1949 and 2006 were classified based on confinement, gradient, number of channels and sinuosity. Subsequently, it was determined which reaches have changed type over time and whether 
changes in reach types were associated with changes in land cover in the riparian zone and surrounding floodplain.

\section{What was the historic distribution and relative abundance of floodplain and channel} habitat, and how has this changed through time?

Unconfined streams associated with complex floodplain and channel features are especially indicative of high quality salmonid habitat. Floodplain channels are critical habitat for juvenile salmon which often use these features for foraging and refuge (Brown and Hartman 1988, Jeffres et al. 2008). Furthermore, salmonids reared in floodplain channels were found to have higher growth rates (and subsequent survivorship to adult) than those remaining in the adjacent main-stem (Sommer et al. 2001, Jeffres et al. 2008). Floodplain areas also provide important services to the main channel (e.g., nutrient and large wood input, filtering of runoff and temperature regulation). A significant reduction in floodplain habitat and connectivity due to road construction, water withdrawal and channelization in the Wenatchee system (Andonaegui 2001, Honea et al. 2009) have engendered concern about the quality of remaining habitat. Finally, in-channel habitat features, such as vegetated islands, typically form downstream of large wood jams making them indicative of high biological diversity (Beechie et al. 2006). Therefore, changes in floodplain and channel habitat features (i.e., dry and slow/stagnant side channels, ponds/wetlands and vegetated islands) were mapped in the historic and modern imagery. Subsequently, changes in area and number of features over time were quantified across the watershed. Furthermore, these changes were examined relative to the amount of anthropogenic modification which had occurred in the floodplain. 


\section{Methods}

\section{Study Site}

The study area consists of the Wenatchee River and four main salmonid-bearing tributaries (Chiwawa, Little Wenatchee and White Rivers and Nason Creek). These five streams are located in central Washington State in Chelan County (Figure 1) and are referred to collectively as the Wenatchee system. The Wenatchee River watershed is approximately $3,550 \mathrm{~km}^{2}$ ( $\sim 850,000$ acres); its mouth is approximately $750 \mathrm{~km}$ upstream of the confluence of the Columbia and the Pacific Ocean, a section of river containing seven dams as of 1971. Climate and vegetation vary greatly due to geology and topography. For example, the western slopes contain glaciers, moist alpine meadows and open forests giving way to dense coniferous forest at lower altitudes, whereas the drier eastern slopes are covered by glaciers and alpine grasslands transitioning to drought-tolerant coniferous forest (Jorgensen et al. 2009). Primary land uses are forestry, wilderness, agriculture, rangeland, residential and recreation; the majority of this land ( 76\%) is managed by the U. S. Forest Service (USFS). The Wenatchee system currently contains four anadromous salmonids: Chinook $(O$. tshawytscha) and sockeye (O. nerka) salmon, steelhead trout (O. mykiss) and bull trout (Salvelinus confluentus). Coho salmon (O. kisutch) have been extirpated from this watershed. The Wenatchee system was historically a highly productive salmonid spawning area (Chapman et al. 1995, Ford et al. 2001, ICTRT 2003) and now contains four evolutionary significant units (ESUs) of salmon, two of which are currently listed as endangered:

- Upper Columbia River spring-run Chinook salmon (O. tshawytscha) - Endangered.

- Upper Columbia River summer/fall-run Chinook salmon (O. tshawytscha). 
- Upper Columbia River steelhead (O. mykiss) - Endangered.

- Lake Wenatchee sockeye salmon (O. nerka).

\section{Aerial Photographs}

Historic landscape conditions were reconstructed using the oldest, complete photo coverage of the Wenatchee system (USFS circa 1949 at a 1:20,000 scale). Just over 300 contact prints were created from the original negatives by the National Archives and Records Administration. The prints were scanned at high resolution (1200dpi) on an Epson Expression $1640 \mathrm{XL}$, a graphics grade scanner. Modern landscape conditions were determined from the USDA compressed county mosaic 1-m color orthophoto (original photos captured at 1:40,000) for Chelan County (circa 2006). Due to seasonal differences in imagery acquisition, modern imagery had more visible standing water than historic photos, and thus a greater total wetted area on the modern photos was potentially visible. Modern imagery was primarily captured in July 2006 (monthly median streamflow of $2800 \mathrm{ft}^{3} / \mathrm{s}$ ); historic imagery was captured in September 1949 (monthly median streamflow of $942 \mathrm{ft}^{3} / \mathrm{s}$; Figure 2). In comparing historic and modern median discharges with 78 years of median stream discharges for all months, median July 2006 flows were in the $72^{\text {nd }}$ percentile and September 1949 flows were in the $17^{\text {th }}$ percentile.

\section{Creation of Orthomosaic}

Orthorectification is the process of removing geometric error, radial displacement and tilt and relief distortions from aerial photographs so that orthophotos are of consistent scale and 
derived measurements are planimetrically accurate. There were five major steps in the orthomosaicing process, most of which were performed using the Alta Photogrammetric Suite (APS) Version 7.x. First, each scanned image underwent interior and exterior orientation to determine the 3-D space of each photo and account for aircraft movement, respectively. Second, ground control points (GCPs) and a USGS 30-m digital elevation model (DEM) was used to relate the uncorrected (raw) image to the modern orthoimagery. It was assumed that the difference in time between historic airphoto capture and creation of the modern DEM was short enough that the geologic changes in topography would be negligible making the modern DEM usable for historic orthorectification. Least-squares regression then transformed all remaining (unreferenced) pixels to map coordinates. The goal for RMSE values (the standard error around the regression equation) for GCPs and the overall equation was $<1$ pixel resulting in an error of $\pm 0.25 \mathrm{~m}$. Third, bilinear interpolation (which created new digital numbers) and a transformation equation were used to warp each raw image into a planimetric orthophoto. Finally, individual orthophotos were mosaiced to create a single, contiguous layer usable with other spatial data. A detailed review of the orthorectification methods is provided in Appendix I.

\section{Image Classification}

Four different classification schemes representing multiple scales (Figure 3) were digitized manually. Each classification scheme was designed to measure a specific riverine or landscape feature of ecological relevance and they are further explained in the following paragraphs. 


\section{Historic extent of the 100-year floodplain}

The 100-year floodplain limits the extent of riverine influence on the terrestrial environment and includes the zone of major channel and floodplain morphological change. The original extent of the historic floodplain is unknown and not easily determined from modern flood maps (e.g., Federal Emergency and Management Agency) as subsequent landscape modifications (i.e., agriculture, levees, dams, etc.) have dramatically altered the floodplain. Thus, the original floodplain extent was manually digitized using a hillshade derivative of a USGS 10-m DEM and 1:24,000 topoquads and adjusted using historic orthorectified photos where appropriate. Subsequent mapping and analyses occur only within the boundaries of the historic floodplain.

\section{Generalized land cover scheme (Question 1)}

Historic and modern land cover (agriculture, urban and forest/shrub) and road networks were digitized on-screen from orthoimagery in ArcGIS 9.x (Table 1) to identify areas where the historic floodplain has subsequently been fragmented or converted to other uses. Roads were digitized as lines and buffered by 5 meters to provide areal measurements. A 4 hectare minimum mapping unit was implemented, such that any patch of agriculture or urban land $\geq 4$ ha was delineated (Lunetta et al. 1997), whereas patches $<4$ ha were not distinguished. In addition, infrastructure (buildings, roads, etc.) located within an agricultural or urban polygon was not distinguished separately. However, in order to ensure highly accurate representation of riparian vegetation, any bank side forested vegetation (regardless of patch size) nested within a larger agriculture or urban polygon was delineated. This approach helped ensure no forested areas were missed in subsequent change detection analyses and 
ensured areal estimates of forest loss were conservative (i.e., not artificially inflated). Because of its widespread use as a landscape indicator, percent area of anthropogenic modification to the floodplain was quantified by grouping agriculture, urban and roads. Rivers were then grouped according to level of anthropogenic modification based on percent, extent and type of modification. Finally, the modern land cover classification was groundtruthed using field data collected with a Trimble GPS Pathfinder ProXT receiver (a subsample of GPS points are shown in Figure 4). This accuracy assessment of the modern land cover interpretation was meant to provide context for a possible "best case" accuracy of the historic land cover interpretation, which was impossible to ground truth directly.

\section{Stream reach type scheme (Question 2)}

Streams were divided into reach segments and then classified by reach type (Table 1B). Several steps were used to identify individual reaches. First, stream centerlines and banks were manually digitized from the orthoimagery. Streams were then divided into reaches approximately 10 to 20 stream widths in length (Montgomery and Buffington 1997) starting at the stream's mouth and iteratively moving upstream using the digitized vector data and the 10-m DEM. Reach length boundaries were digitized as to distinguish discrete reach types. Reach segments were constant through time as the average width of a reach did not vary greatly between the two time periods. Second, each reach was classified as either confined (i.e., channel restricted by an adjacent hillslope) or as unconfined. By definition, channel movement of unconfined reaches is less restricted thereby increasing the potential for creation of off-channel floodplain habitats (i.e., floodplain channels, ponds and wetlands). A channel confinement ratio (CCR; floodplain width / channel width) was determined for each 
reach, where $\mathrm{CCR} \leq 3.8$ indicated confined and $\mathrm{CCR}>3.8$ indicated unconfined reaches (Hall et al. 2007). Third, unconfined channels were further classified into four reach types (straight, meandering, island-braided and braided) based on number of threads per channel, sinuosity and tone (Beechie et al. 2006). Confined channels were further classified according to slope (using the DEM) and in descending gradient include: cascade, step pool, plane bed and pool-riffle (Montgomery and Buffington 1997). Additional detail is provided in Table $1 B$.

Floodplain and channel habitat scheme (Question 3)

Floodplains and channels with a higher abundance of important habitat features, such as connected side channels or vegetated islands, indicate potential areas of productive salmonid habitat. Therefore, floodplain and channel habitat features (Table 1C) were manually digitized from historic and modern orthoimagery. Total area and number of habitat features were summarized by reach. Floodplain (off-channel) habitats included slow/stagnant channels, dry channels and ponds/wetlands; in-channel habitat included vegetated islands.

\section{Change Detection and Statistical Analyses}

Land cover changes over time (Question 1) were quantified in a transition matrix. Within each cover class in 1949, 1000 random points at least $100 \mathrm{~m}$ apart were compared to land cover in 2006 (a subsample of points is shown in Figure 4). To examine changes in relative abundances of different land cover types, total area of individual land cover classes were compared over time within the floodplain and riparian areas. The percent of floodplain and 
riparian area modified by anthropogenic alterations (urban, agriculture and roads) was determined for each stream.

Changes over time in reach type (Question 2) for all reaches $(n=424)$ were summarized using a transition matrix. Next, a subset of these reaches were examined further, primarily (a) to examine the change in a given reach over time, but also (b) to compare characteristics of reaches which changed over time to those that did not. First, for this subset of reaches, changes in reach characteristics (i.e., sinuosity, length, anthropogenic modification) over time were compared using a paired t-test of Wilcoxon signed ranked scores (due to nonnormality). Second, initial (1949) reach characteristics of transitioning and non-transitioning reaches were compared to determine if initial conditions of transitioning reaches differed from those reaches which did not transition. Lastly, ending (2006) conditions, as well as the total amount of change over time, were compared among transitioning and non-transitioning reaches. For such comparisons, a one-way ANOVA Kruskal-Wallis was used to account for non-normality.

Changes in total area and number of habitat types (Question 3) were totaled across the study site, as well as for river systems grouped according to level of anthropogenic modification. Floodplain and channel habitat changes were also summarized by reach. Changes in mean area and mean number of features over time were compared using paired t-tests of Wilcoxon signed rank scores. Furthermore, as reach area and length vary with time, floodplain habitats were standardized relative to floodplain area (e.g., area of dry channels / hectare) and vegetated islands standardized by reach length (e.g., number of islands / km). 
All statistical analyses were completed using SAS 9.1. In all analyses, $\alpha=0.05$; losses in measured attributes are represented with negative values. As each analysis (either paired ttests of Wilcoxon signed rank scores or one-way ANOVA Kruskal-Wallis) was an independent test (i.e., not multiple pairwise comparisons) of discrete values, Bonferroni corrections of alpha values were inappropriate. However, the lack of a holistic model incorporating all variables simultaneously limits the potential inferences made from these analyses.

\section{Results}

Overall accuracy of the modern land cover classification (Question 1) was 88\%, with a kappa coefficient of 0.80 (Table 3). Producer's accuracies for individual classes ranged from 98\% to $69 \%$; user's accuracies ranged from $94 \%$ to $82 \%$. Agriculture and urban classes had high producer's accuracies (92\% and 98\% respectively) indicating that these classes had low errors of omission and very few of these classes were missed. Forest/shrub has a lower producer's accuracy (69\%) and was primarily misclassified as agriculture resulting in an underestimates of the forest/shrub class. Agriculture and forest/shrub had higher user's accuracies ( $89 \%$ and 94\% respectively) indicating low errors of commission and that areas mapped as such were unlikely to be highly overestimated. Urban had a lower user's accuracy $(82 \%)$ indicating higher error of commission. This was due to agriculture being misclassified as urban and thereby slightly overestimating the urban class. 
What was the historic distribution and relative abundance of land cover in the floodplain and riparian zone, and how has this changed through time?

The total area of different land cover types has changed from 1949 to 2006. In 1949, floodplain and riparian areas were dominated by forest/shrub and, to a lesser extent, agriculture; urban land cover was the least abundant (Figure 5). Urban areas showed the greatest increase in total area over time in floodplain and riparian areas $(602 \%$ and $372 \%$ respectively), whereas agriculture showed the largest decline (25\% and 19\% respectively; Figure 5). Forest/shrub land cover decreased by only $4 \%$ in total area in floodplain and riparian areas (Figure 5). The primary land cover transition observed was to urban (Table 2). Both forest/shrub and agriculture overwhelmingly transitioned to urban (with probabilities of change of 0.17 and 0.41 respectively). Urban cover was highly persistent, with a 0.98 chance of remaining urban over time. Forest/shrub and agriculture classes were the less persistent ( 0.78 and 0.58 probabilities of remaining) over time.

When considering all anthropogenic floodplain modifications collectively (agriculture and urban areas and roads), the most highly modified systems as of 2006 were the Wenatchee River (63\%) and Nason Creek (7\%; Figure 6). Despite the small areal extent of modification in Nason Creek, the extensive road network along-side, and often within, the river corridor could potentially result in disproportionate affects on riverine condition. In contrast, the lowest levels of modification in 2006 were observed in the Little Wenatchee (1\%), White (3\%) and Chiwawa River (4\%) floodplains (Figure 6). Modifications to the Chiwawa River floodplain were largely a result of a single, isolated, rural housing development at the mouth of the river, with arguably less potential for affecting the entirety of the stream. Localized 
effects (such as a housing development) could more easily be mitigated via riparian management or local education efforts. Therefore, for subsequent analyses, the Chiwawa, Little Wenatchee and White Rivers were identified as "Less Modified" whereas the Wenatchee River and Nason Creek were referred to as "Highly Modified" systems.

What were the original abundances of historic stream reach types, and how have they changed through time?

Changes in the relative abundance of different reach types between historic and modern periods are shown for all 424 reaches in the Wenatchee system (Figure 7). Reach type classifications of 68 channels changed from 1949 to 2006 (Table 4). The number of straight, island-braided and plane bed reaches increased in number by $2 \%, 67 \%$ and $11 \%$ respectively, while the number of meandering and pool/riffle reaches decreased by $28 \%$ and $41 \%$ respectively (Figure 7). Reaches which were meandering or island braided in 1949 overwhelmingly transitioned to straight channels with probabilities of change of 0.24 and 0.42 respectively (Table 4). Concomitantly, the probabilities of meandering and island braided channels persisting over time were 0.66 and 0.54 respectively (Table 4). In contrast, straight reaches in 1949 were highly persistent across the landscape, with a 0.91 probability of remaining straight in 2006 (Table 4).

Specific reach type transitions of particular ecological significance (noted in bold in Table 4) were examined in more detail; specifically, meandering and island braided channels that transitioned to straight, as well as straight reaches that transitioned to island braided. For these reaches, specific characteristics of the channel, floodplain and riparian area were 
compared to characteristics of reaches which did not transition (Table 5). Comparisons were made among initial and ending condition of reaches as well as the amount of change observed over time (Table 5). These comparisons are explained in more detail below.

Eighteen meandering reaches transitioned to straight (Table 4) and showed corresponding decreases in mean sinuosity ( 1.6 to $1.3, p=0.0003$ ) and mean reach length ( 834 to $690 \mathrm{~m}, \mathrm{p}$ $=<0.0001 ;$ Table 5A). Furthermore, percent floodplain and riparian anthropogenic modification increased $3 \%(p=0.0009)$ and $2 \%(p=0.0327)$ respectively $($ Table $5 \mathrm{~A})$. In contrast, forty-nine meandering reaches in 1949 (which remained so in 2006) exhibited no changes in sinuosity or reach length (Table 4) despite the fact that both floodplain and riparian anthropogenic modification significantly increased by $\sim 2 \%$ over time $(p=0.0084$ and 0.0305 respectively). Furthermore, the mean change over time in modification to floodplain and riparian areas seen in transitioning and non-transitioning reaches was statistically similar (Table 5A). Meandering channels that transitioned to straight, however, had lower initial $(\mathrm{p}=0.0003)$ and ending $(\mathrm{p}=<0.0001)$ mean sinuosity than channels which remained meandering as of 2006 (Table 5A). Additionally, meandering channels that transitioned to straight exhibited greater mean decreases over time than non-transitioning channels in sinuosity $(-0.26$ vs. $-0.12 ; p=0.0012)$ and reach length $(-144.3$ vs. $-47.9 \mathrm{~m}, \mathrm{p}=$ $<0.0001$; Table 5A). While reach lengths were similar in 1949, by 2006 reach lengths of meandering channels were longer than those that transitioned to straight (796 vs. $689 \mathrm{~m}, \mathrm{p}=$ 0.0363; Table 5A). 
Just under half of island braided reaches $(n=10)$ transitioned to straight (Table 4$)$ and exhibited a decrease in reach length (921 to $911 \mathrm{~m}, \mathrm{p}=0.0481$ ) and an increase in floodplain $(2 \%, p=0.0078)$ and riparian $(3 \%, p=0.0234)$ modification (Table 5B). Furthermore, the area of vegetated islands decreased from 4.9 to $1.8 \mathrm{~m}^{2} /$ reach $(\mathrm{p}=0.0273)$ within these reaches (Table 5B). In contrast, the thirteen island braided reaches that remained island braided (Table 4) showed no significant change in sinuosity, reach length, anthropogenic modification or area of vegetated islands over time (Table 5B). When examining the dynamics of island-braided channels over time, significant differences were seen between reaches which transitioned to straight versus those remaining island braided. Initial (1949) and ending (2006) reach length was shorter in transitioning channels than in those remaining island braided $(\mathrm{p}=0.0029$ and 0.0043 respectively; Table 5B). However, reaches that remained island braided had greater initial and ending anthropogenic modification of floodplain $(\mathrm{p}=0.0217$ and 0.0255 respectively) and riparian $(\mathrm{p}=0.0349$ and 0.0407 respectively) areas than those that transitioned to straight (Table 5B).

Twenty straight reaches transitioned to island braided (Table 4). These reaches showed no significant change over time in sinuosity or reach length, however floodplain and riparian modification increased $3 \%(p=0.0038)$ and $2 \%(p=0.0131)$ respectively (Table $5 C)$. Historic straight reaches that transitioned to island braided were compared to nontransitioning island braided channels in order to determine if some historic island braided channels had been missed and inadvertently classified as straight. Initial and ending sinuosity did not differ among these two groups (Table 5C). However, initial and ending 
floodplain $(\mathrm{p}=<0.0001$ and $<0.0001$ respectively) and riparian $(\mathrm{p}=0.0002$ and 0.0003

respectively) modification was significantly higher in non-transitioning reaches (Table 5C).

What was the historic distribution and relative abundance of floodplain and channel habitat, and how has this changed through time?

Historically, there was a greater total area of slow/stagnant channels across the study site. Both area and number of dry channels were greater historically. Vegetated islands and pond/wetlands were historically less abundant (Figure 8). Across the entire study site, the area of habitat features associated with channel migration (slow/stagnant and dry channels) has substantially decreased over time. While the total area of slow/stagnant channels decreased $26 \%$, the number of features did not change (Figure 8). Dry channels decreased in total area (33\%) and number (30\%; Figure 8). In contrast, vegetated islands and floodplain ponds and wetlands have increased from 1949 to 2006 (Figure 8). The total area of floodplain ponds and wetlands increased $4 \%$ and in-channel vegetated islands increased by 8\% (Figure 8). Furthermore, the number of ponds/wetlands and vegetated islands increased $46 \%$ and $83 \%$ respectively (Figure 8 ).

Results at the reach level mirror trends across the watershed (Figure 8). For comparisons at the reach level, a subset of the 424 reaches that contained floodplain and channel habitat features in either year was compared over time. A decrease in mean area $(-0.006 \mathrm{ha} / \mathrm{reach}, \mathrm{p}$ $=0.0168)$ and number $\left(-9.5 \times 10^{-07}, \mathrm{p}=0.0282\right)$ of dry channels per reach was found (Table 6). In contrast, an increase in mean area $(0.77 \mathrm{ha} /$ reach, $\mathrm{p}=0.0220)$ and number $\left(8.9 \times 10^{-04}, \mathrm{p}\right.$ $=<0.0001)$ of vegetated islands was found (Table 6). 
Lastly, changes in habitat features were compared according to levels of floodplain modification (Figure 9). In highly modified floodplains (defined in Figure 6), all habitat features decreased in total area, yet increased in number (Figure 9). In less modified floodplains, slow/stagnant and dry channels decreased in area and number of features, while area and number of ponds/wetlands and vegetated islands increased (Figure 9). These changes further support the conclusion presented above that habitat features associated with channel migration (slow/stagnant and dry channels) are decreasing in total area.

Changes in reach level habitat features were examined based on level of anthropogenic floodplain modification. In reaches with less modified floodplains, a decrease in mean area $(p=0.0088)$ and number $(p=0.0106)$ of dry channels was observed, while an increase in mean area $(p=0.0376)$ and number $(p=0.0249)$ of vegetated islands was observed (Table 7). In highly modified floodplains, an increase in mean area of pond/wetlands $(p=0.0039)$ and vegetated islands $(\mathrm{p}=<0.0001)$ was observed (Table 7). Therefore, regardless of the level of modification to the floodplain, an increase in area of vegetated islands was found.

\section{Discussion}

Assessing the classification accuracy of historic maps is extremely problematic (Schulte et al. 2002). Here, the accuracy of the modern classification was assessed to help quantify the likely "best case" scenario of the historic classification. The accuracy assessment of the modern land cover classification suggests several things. With an overall accuracy of $88 \%$, the digitization of the modern land cover was highly accurate. The accuracy of the historic 
land cover classification is unlikely to exceed the accuracy of the modern classification. Furthermore, if modern errors of omission and commission for individual classes bear any relevance for the historic classification, some areas of historic forest/shrub may have been misclassified as agriculture, thus under-representing historic abundance of forest/shrub by $22 \%$. Conversely, the historic abundance of urban areas may have been overestimated as historic agriculture might have been occasionally misclassified as urban by $11 \%$.

What was the historic distribution and relative abundance of land cover in the floodplain and riparian area, and how has this changed through time?

Historically urban land cover was the least abundant cover type; however, it exhibited the greatest increase in total area of all the cover types. Forest/shrub was historically the most abundant class followed closely by agriculture. This indicates that much of the original floodplain forests of the Wenatchee system had already been converted to agriculture by 1949. Forest/shrub land cover decreased only slightly from 1949 to 2006 indicating the great majority of urban expansion occurred in areas already occupied by agricultural land. Urban land cover was the most persistent and rapidly expanding class over time. Agriculture and forest/shrub land covers overwhelmingly converted to urban whereas urban areas rarely converted to another cover type. The Wenatchee River has been disproportionately modified by urban development as urban expansion occurred primarily in the Wenatchee River floodplain but not along the other four tributaries of the system.

The patterns and types of anthropogenic modification differed among sub-basins. Modification along the Wenatchee River floodplain was primarily due to agriculture and 
urban development whereas Nason Creek was highly modified due to road development. Roads and other developments have confined the channel and likely contributed to the reductions in sinuosity seen in some reaches (Andonaegui 2001). Furthermore, much of the road development took place in the riparian zone where it may have a greater deleterious affect on stream function such as increased sediment loading, reduced large wood input or greater water temperature fluctuations (Hicks et al. 1991). In contrast, the Chiwawa River exhibited less floodplain modification, and the observed modification largely reflected a single housing complex at the river's mouth, while the rest of the floodplain remains relatively undeveloped.

As a result of differing types of anthropogenic modifications and their spatial distribution, mitigation efforts should also vary among sub-basins. The Wenatchee River would greatly benefit from restoration efforts designed to counter the effects of agriculture and urban expansion, including riparian management to decrease surface runoff and sedimentation, buffer stream temperature and increase large wood input. Nason Creek would benefit from restoration efforts designed to mitigate road impacts. Drainage ditches and/or culverts could help manage runoff and sedimentation, especially for unpaved roads, from directly entering streams and negatively impacting fish populations such as egg incubation (Hicks et al. 1991) protecting the floodplain from future road development. Furthermore, riparian restoration and large wood input could help reintroduce natural ecosystem processes. The remaining three rivers (the Chiwawa, White and Little Wenatchee) are relatively undeveloped and would therefore benefit more from conservation efforts intended to protect and maintain the 
natural fluvial-geomorphic and ecological processes (channel migration, annual flooding, large wood input, etc.) still occurring.

Wang et al. (1997) showed that agricultural land covering more than $50 \%$ of a watershed can negatively impact stream biotic integrity (an index developed from information on the structure, composition and functional organization of fish assemblages; Lyons et al. 1996) and stream habitat quality (developed from stream metrics, channel habitat and riparian conditions; Simonson et al. 1993). Furthermore, historic agriculture may profoundly decrease modern fish and in-stream invertebrate diversity (Harding et al. 1998). In 1949, approximately $55 \%$ of the Wenatchee River floodplain was occupied by agriculture. Subsequent conversion of agricultural areas to urban likely exacerbated some aspects of stream habitat degradation. Wang et al. (1997) reported that as little as 10-20\% urban land cover can severely impact stream biotic integrity and habitat quality (as defined above). Furthermore, other studies have shown that urban and road cover types negatively impact salmonid habitat as well (Hicks et al. 1991, Beechie et al. 1994, Roth et al. 1996). The floodplain of Wenatchee River was $62 \%$ modified as of 2006 , of which $20 \%$ was due to urban development. Given that the quantity of both historic agricultural and modern urban land cover in this system surpass the threshold levels found to have deleterious impacts on stream conditions, salmonid habitat quality is likely to be severely degraded in the Wenatchee River. 
What were the original abundances of historic stream reach types, and how have they changed through time?

The Wenatchee system is characterized by a loss of meandering reach types between 1949 and 2006. Interestingly, meandering streams (circa 1949) that transitioned to straight were under similar pressure from anthropogenic modification to their floodplain and riparian areas as those that remained meandering (both significantly increased over time and had statistically similar starting and ending levels of modification). Furthermore, transitioning streams started with similar average reach lengths compared to those that remained meandering. What differed, however, was that transitioning reaches had statistically significant lower levels of sinuosity in 1949 and 2006 and exhibited a significantly greater decrease in sinuosity over time. Stream reaches closer to the sinuosity threshold between meandering and straight $($ sinuosity $=1.5)$ appear to have a greater probability of transitioning to straight. Channel migration (associated with meandering reaches) is responsible for large wood input, increased in-stream habitat variability (due to bank cutting and pool/riffle formation) and increased abundances of off-channel habitat (Montgomery 1999, Naiman et al. 2000). A transition from meandering to straight represents a loss of these functions and overall habitat complexity which are important for salmonids (Beechie et al. 1994, Beechie et al. 2006). Therefore, channels that are near this transition threshold should be given priority for protection and/or restoration. Possible restoration efforts for meandering channels could include reducing or eliminating development within the river's floodplain or use of setback levees which permit overbank flooding and lateral channel migration (Gergel et al. 2002a). 
Nearly half of the historic island braided reaches also transitioned to straight. These transitioning reaches exhibited statistically significant decreases in reach length and were subjected to significant increases in anthropogenic modification over time (in both floodplain and riparian areas) than reaches that remained island braided. Decreases in reach length are generally associated with decreases in sinuosity and lateral channel migration, a process which fosters large wood input to a stream. Furthermore, anthropogenic modification of floodplain and riparian areas often results in reduced availability of bank-side large wood. Island formation is dependent, in part, on large wood input (Abbe and Montgomery 2003, Gurnell et al. 2005). Thus, reduced stream length and increased anthropogenic modification have likely contributed to a reduction of available large wood and the subsequent decrease in the number of island braided reach types observed in this system. Island braided reaches typically have the highest biological diversity and produce and maintain higher quality salmonid habitat than other reach types examined in this study (Beechie et al. 2006, Zanoni et al. 2008). Therefore, island braided reaches should also be priorities for conservation or restoration. Possible restoration efforts that promote formation of in-channel islands could include riparian management that promotes growth of bank-side vegetation for potential large wood input. Managers could also add large wood to the channel in key locations forming jams that would aid in-channel islands formation. However, such efforts have generally not been extremely successful, especially in larger systems (Thompson 2006, Stewart et al. 2009).

Historically, the Wenatchee system was dominated by straight channels which out-numbered all other reach types combined (245 vs. 179). The relative abundance of straight reach types 
is similar in 2006 ( 250 vs. 174). However, as discussed above, there were many transitions among channel forms suggesting a dynamic equilibrium among reach type transitions, but this is a misleading assumption for two reasons. First, many meandering and island braided reaches transitioned to straight while very few made the reverse transition. Second, the observed transitions of historic straight channels that transitioned to island braided are more likely a result of mapping error (discussed further below in the Mapping Error section). Thus, the $2 \%$ increase in abundance of straight streams (Figure 7) is likely highly conservative. Correcting this misclassification would decrease the abundance of historic straight channels, further increasing the magnitude of change over time in straight reach types, making the general trend of channels transitioning to straight much more evident.

While transitions among stream reach types are a natural geomorphic process over the long term, the predominance of certain reach type transitions can be problematic in the context of salmon management. Straight channels have the lowest biological and habitat diversity of reach types in this study (Beechie et al. 2006). The general trend of all reaches transitioning to straight and straight channels persisting through time alludes to a net loss of high quality salmonid habitat. The tendency for straight reaches to remain straight suggests that the Wenatchee system is under external pressure (likely anthropogenic modification) that decreases the likelihood of streams naturally transitioning among channel forms once a channel has been straightened. 
What was the historic distribution and relative abundance of floodplain and channel habitat, and how has this changed through time?

The Wenatchee River watershed was historically richer in floodplain habitat features associated with lateral channel migration. Streams in the Wenatchee system have lost a substantial amount of dry channel habitats when measured either in terms of area or number. Slow/stagnant channels have also decreased considerably in area. The general trend of stream straightening corresponds to losses in off-channel habitats; as streams migrate less across the floodplain, fewer new off-channel features are created and more may become disconnected from the main channel. Dry and slow/stagnant channels are relict stream channels (either with or without standing water at the time the photo was taken) that provide critical refuge and rearing habitat for salmonids (Sommer et al. 2001, Jeffres et al. 2008). Thus the loss of dry channels, combined with areal losses of slow/stagnant channels, reduces two important types of habitat that were previously available for salmonids.

There was also a loss of habitat associated with channel migration even in reaches with the least anthropogenic floodplain modifications. Such reaches exhibited a decrease in area and number of dry and slow/stagnant channels. While these results were unexpected, they may reflect the natural variability in riverine systems. Reaches naturally transition between various channel forms (Beechie et al. 2006) and subsequent decreases in floodplain habitat would be expected. While most of the meandering and island braided reach type transitions to straight were likely due to anthropogenic changes in the watershed, a certain portion of these may have been due to natural processes. It is expected that these natural transitions would be observed in floodplains with low levels of floodplain modification where the 
transitions would not be confounded by human activity. The subsequent losses in floodplain habitat observed in low modification floodplains would likely reflect background fluvialgeomorphic transitions. Alternatively, these changes observed in less modified floodplains could be the result of either upland land use practices not quantified in this study or upstream modification in areas with highly modified floodplains.

Reaches associated with highly modified floodplains exhibited changes typically associated with anthropogenic activities (Roth et al. 1996, Wang et al. 1997, Jungwirth et al. 2002). All habitat features examined (slow/stagnant and dry channels, pond/wetlands and vegetated islands) decreased in area, yet increased in number, indicating fragmentation of these habitats through time. The primary anthropogenic modification that occurred along the Wenatchee River between 1949 and 2006 was conversion of agricultural areas to urban uses with concomitant increases in impervious surfaces and road densities. In some cases (e.g., Nason Creek), higher road densities were observed in the riparian corridor, and occasionally, roads directly crossed the channel (Figure 6B; Andonaegui 2001). Thus, conversion of agricultural land to urban uses and an expanding road network have reduced the total area of floodplain and channel habitat and fragmented the remaining habitat into smaller, disconnected features. Mechanisms other than anthropogenic actions which may be driving changes in pond/wetlands (i.e., standing water) and vegetated islands (i.e., mapping error) are discussed in the error section below.

The types of losses of floodplain and channel habitat due to human activity in the watershed are not unique to the Wenatchee system. Many studies have linked anthropogenic 
modification of floodplain and riverine systems to altered terrestrial-aquatic interactions and changes in salmonid habitat quality and availability. Stream straightening led to fundamental changes in stream morphology, greatly reducing in-stream salmonid habitat in the Puget Lowlands (Washington, USA; Collins et al. 2002). Hydromodification (diking, ditching, dredging) associated with agriculture and urban land uses of the Skagit River (Washington, USA) greatly reduced floodplain channel habitat, which was subsequently linked to significant decreases in coho smolt production (Beechie et al. 1994). A historic reconstruction of the Danube River (Austria) demonstrated that channel straightening led to decreases in off-channel habitat and reductions in nutrient exchange and organismal movement between floodplain channels and the main stem (Hohensinner et al. 2004).

\section{Sources of Mapping Error}

Mapping errors also likely influenced the results of this study. Severe glare (or possibly overexposure of imagery) within channels on historic imagery was much more prevalent in narrow headwater streams than in the Wenatchee main stem. Thus, detection of in-channel vegetated islands in headwater streams was extremely difficult. It is likely that many historic straight channels (that appeared to have transitioned to island braided reaches) may have been identified as island braided in 1949 had better image contrast been attainable. That is, more vegetated island in-channel habitat features would have been identified in the historic landscape. Furthermore, 18 of the 20 straight to island braided transitioning reaches were located in narrow headwater streams where glare was an issue. Thus, while the result that island braided reaches increased $67 \%$ over time is possible, it is highly unlikely, especially given the level of anthropogenic modification to floodplain and riparian areas. 
Anthropogenic modification typically results in forest stand removal and stream straightening, actions that would likely decrease the potential of vegetated islands to form.

Additional evidence suggests that mapping error particularly influenced the identification of island braided systems. Comparison of characteristics of non-transitioning island braided channels with those of supposed straight reaches that transitioned to island braided are notable. Sinuosity is a key indicator of the potential of a stream to create in-channel islands. The two sets of channels showed no difference in initial and ending sinuosity. Furthermore, the supposedly straight reaches that transitioned to island braided had significantly less floodplain and riparian anthropogenic modification which indicates a greater potential for large wood recruitment into the stream. Thus, it is likely that had the imagery been more clear, many of the "straight to island braided" transitions would have been originally classified as island braided in 1949. The addition of these historic islands would have reduced the perceived increase in area and number of in-channel habitat features over time.

Lastly, differences in timing of imagery acquisition and water storage within the watershed may have resulted in perceived changes in area and number of floodplain ponds and wetlands. Modern imagery was captured primarily in July during higher stream discharge $\left(2800 \mathrm{ft}^{3} / \mathrm{s}\right)$, whereas historic imagery was captured during lower September discharge (942 $\mathrm{ft}^{3} / \mathrm{s}$ ). The higher flows and water levels associated with the modern imagery would likely inflate areal measurements of ponds and wetlands. 


\section{Conclusion}

\section{Implications for Salmonids}

Fish species worldwide are experiencing population declines (Nehlsen et al. 1991, Vitousek et al. 1997); much of these losses in diversity can be attributed to anthropogenic habitat alteration (Nehlsen et al. 1991, Jungwirth et al. 2002). Historic agricultural and modern urban land cover can negatively impact salmonid habitat quality (Wang et al. 1997, Harding et al. 1998). Thus, large historic abundances of agriculture and subsequent conversion to urban uses have likely reduced salmonid habitat quality in the Wenatchee system. Island braided and meandering reach types are most likely to contain high quality salmonid habitat (Beechie et al. 2006, Zanoni et al. 2008); thus, loss of these reach types have likely decreased the high quality in-stream and off-channel habitat available to salmonids in the study area. Straight channel types and urban land cover are both highly persistent and increasing in dominance within the study area and will likely result in further river-floodplain degradation in the absence of any active conservation, restoration or management plans.

The increase in anthropogenic floodplain modification and decline in meandering channels likely reduced the potential of streams to develop off-channel habitat. Reestablishment of channel migration helps create a self-sustaining mechanism for river restoration that can lead to long-term improvements in stream habitat (Ward et al. 2002). This could be accomplished by reducing or eliminating floodplain development; removing or modifying flows of dams; or using setback levees. Furthermore, fish population recovery can benefit from restoration of floodplain habitat (Beechie et al. 1994, Sommer et al. 2001, Jeffres et al. 2008). Thus, the declines in slow/stagnant and dry channels in the Wenatchee system have likely reduced the 
availability of high quality salmonid habitat. Furthermore, increased habitat fragmentation, particularly in highly modified floodplains, may have also made remaining floodplain habitats less accessible to salmonids.

\section{Applications for Management}

Detailed high resolution information regarding historic landscape conditions are of paramount importance for fish management plans and provide the necessary information needed to reconstruct the original abundance and location of salmonid habitat.

Reconstructing the historic river floodplain of the Wenatchee system can help locate specific areas of prime historic habitat; comparison with modern imagery helps determine current status of such areas and locate potential areas for restoration. The results of this study also identify salmonid habitat that has remained intact and should be given priority for habitat conservation. For example, streams approaching the meandering-straight sinuosity threshold $($ sinuosity $=1.5)$ have a greater potential to straighten, representing a loss in high quality habitat. Managers will also be able to use this historic dataset to model how loss of floodplain, riparian and channel habitat has influenced salmonid population declines relative to other factors. Previous studies attempting such models have sited lack of historic data for habitat features as a limiting factor in their analyses (Beechie et al. 1994, Jorgensen et al. 2009). This research provides historic information that can be used to estimate intrinsic habitat potential, a framework used to guide management (ICTRT 2007). Finally, the general methodology used in this study may be adapted to other rivers throughout Canada and the USA where salmonid populations are in decline (e.g., the Fraser River (CA) and the Snake River (USA). 


\section{Tables}

Table 2-1: Description of broad-scale (A) and fine-scale (B - C) classification schemes

mapped in this study, as well as identifying characteristics and scales used for digitization.

A: General land cover

\begin{tabular}{|c|c|c|c|c|}
\hline Class & Description & Identifying Characteristic(s) & $\begin{array}{l}\text { Digitizing } \\
\text { Scale }\end{array}$ & $\begin{array}{l}\text { Minimum } \\
\text { Mapping Unit }\end{array}$ \\
\hline Agriculture & $\begin{array}{l}\text { A conglomerate of } \\
\text { agricultural cover types } \\
\text { (e.g., wheat, corn, hay, } \\
\text { etc.). }\end{array}$ & $\begin{array}{l}\text { Row crops, orchards and plowed } \\
\text { fields. Inclusive of roads. }\end{array}$ & $1: 10000$ & 4 ha \\
\hline Urban & $\begin{array}{l}\text { All urban surfaces (i.e., } \\
\text { concrete, pavement, } \\
\text { etc.). }\end{array}$ & $\begin{array}{l}\text { All built-up features associated } \\
\text { with commercial and residential } \\
\text { areas. Inclusive of roads, } \\
\text { buildings, airfields, etc. }\end{array}$ & $1: 10000$ & 4 ha \\
\hline Forest \& Shrub & $\begin{array}{l}\text { All forested cover types } \\
\text { (deciduous and } \\
\text { coniferous) and shrubs. }\end{array}$ & $\begin{array}{l}\text { All vegetation including trees } \\
\text { (coniferous and deciduous) and } \\
\text { shrubs. Roads not included. }\end{array}$ & $1: 10000$ & None \\
\hline Roads & $\begin{array}{l}\text { Inclusive of all road } \\
\text { surfaces (paved or dirt) } \\
\text { no otherwise included } \\
\text { in agriculture or urban } \\
\text { classes. }\end{array}$ & $\begin{array}{l}\text { Long linear features regardless } \\
\text { of width or use. }\end{array}$ & $1: 10000$ & N/A \\
\hline
\end{tabular}




\section{B: Stream reach type classification}

\begin{tabular}{|c|c|c|c|}
\hline Class & Description & Identifying Characteristic(s) & $\begin{array}{l}\text { Mapping } \\
\text { Scale }\end{array}$ \\
\hline Confined & $\begin{array}{l}\text { Stream reaches without any } \\
\text { distinguishable floodplain. }\end{array}$ & $\begin{array}{l}\text { Floodplain Width/Channel } \\
\text { Width } \leq 3.8 \%\end{array}$ & $1: 4000$ \\
\hline Cascade & $\begin{array}{l}\text { Channels with tumbling } \\
\text { water, steep slopes with } \\
\text { large bed-forming material. }\end{array}$ & Gradient $=7.1-8.0 \%$ & N/A \\
\hline Step Pool & $\begin{array}{l}\text { Channels with oscillating } \\
\text { pools and falls due to } \\
\text { intermittent channel } \\
\text { spanning obstructions. }\end{array}$ & Gradient $=3.1-7.0 \%$ & $\mathrm{~N} / \mathrm{A}$ \\
\hline Plane bed & $\begin{array}{l}\text { Channels with a relatively } \\
\text { featureless bed and no } \\
\text { discrete bars. }\end{array}$ & Gradient $=1.1-3.0 \%$ & $\mathrm{~N} / \mathrm{A}$ \\
\hline Pool/Riffle & $\begin{array}{l}\text { Channel with an undulating } \\
\text { bed creating sequences of } \\
\text { bars, pools and riffles; } \\
\text { substrate is typically gravel. }\end{array}$ & Gradient $\leq 1.0 \%$ & $\mathrm{~N} / \mathrm{A}$ \\
\hline Unconfined & $\begin{array}{l}\text { Stream reaches with } \\
\text { distinguishable floodplains. }\end{array}$ & $\begin{array}{l}\text { Floodplain Width/Channel } \\
\text { Width }>3.8 \%\end{array}$ & $1: 4000$ \\
\hline Straight & $\begin{array}{l}\text { Single threaded channel } \\
\text { with low sinuosity. }\end{array}$ & $\begin{array}{l}\text { Single thread channel; } \\
\text { Sinuosity }<1.5\end{array}$ & $1: 5000$ \\
\hline Meandering & $\begin{array}{l}\text { Single threaded channel } \\
\text { with high degree of } \\
\text { sinuosity. }\end{array}$ & Single thread channel;Sinuosity $>1.5$ & $1: 5000$ \\
\hline Island-Braided & $\begin{array}{l}\text { Multiple threaded channel } \\
\text { with permanently vegetated } \\
\text { islands. }\end{array}$ & $\begin{array}{l}\text { Multiple thread channel; } \\
\text { Dark islands due to presence of } \\
\text { vegetation }\end{array}$ & $1: 5000$ \\
\hline Braided & $\begin{array}{l}\text { Multiple threaded channel } \\
\text { with sand/gravel covered } \\
\text { islands. }\end{array}$ & $\begin{array}{l}\text { Multiple thread channel; } \\
\text { Light islands due to sand/gravel } \\
\text { dominance }\end{array}$ & $1: 5000$ \\
\hline
\end{tabular}




\section{C: Floodplain and channel habitat}

\begin{tabular}{llll}
\hline Characteristic & Description & Identifying Characteristic(s) & $\begin{array}{l}\text { Mapping } \\
\text { Scale }\end{array}$ \\
\hline & Slow/Stagnant Channel & $\begin{array}{l}\text { Water present in channel; minimal/no } \\
\text { movement; connected to the main } \\
\text { channel. }\end{array}$ & $1: 5000$ \\
\cline { 2 - 4 } $\begin{array}{l}\text { Floodplain } \\
\text { Habitat Features }\end{array}$ & Dry Channel & $\begin{array}{l}\text { No water visible in channel; } \\
\text { connected to the main channel. }\end{array}$ & $1: 5000$ \\
\cline { 2 - 4 } & Pond or Wetland & $\begin{array}{l}\text { Stagnant water or wet area in the } \\
\text { floodplain not connected to the main } \\
\text { channel. }\end{array}$ & $1: 5000$ \\
& Vegetated Island & $\begin{array}{l}\text { A vegetated island in the stream (main } \\
\text { channel) completely surrounded by } \\
\text { water. }\end{array}$ & $1: 5000$ \\
\hline $\begin{array}{l}\text { Channel } \\
\text { Habitat Feature }\end{array}$ & & & \\
& & & \\
\hline
\end{tabular}


Table 2-2: Transition matrices showing land cover change from 1949 to 2006 at 3000 randomly generated points: (A) Raw tally matrix of instances of change, (B) Probability matrix $(0.0-1.0)$.

A. 2006

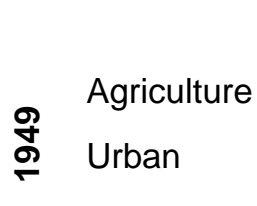

Forest/Shrub

\begin{tabular}{l|l|l|}
\multicolumn{3}{c}{2006} \\
\multicolumn{1}{c}{ Agriculture } & \multicolumn{1}{c}{ Urban } & Forest/Shrub \\
\hline 932 & 664 & 20 \\
\hline 2 & 130 & 0 \\
\hline 66 & 206 & 964 \\
\hline
\end{tabular}

B. 2006

\begin{tabular}{|c|c|c|c|c|}
\hline \multirow{4}{*}{ g্ } & \multirow{4}{*}{$\begin{array}{l}\text { Agriculture } \\
\text { Urban } \\
\text { Forest/Shrub }\end{array}$} & Agriculture & Urban & Forest/Shrub \\
\hline & & 0.58 & 0.41 & 0.01 \\
\hline & & 0.02 & 0.98 & 0.00 \\
\hline & & 0.05 & 0.17 & 0.78 \\
\hline
\end{tabular}


Table 2-3: Accuracy assessment of the general land cover mapped on modern orthoimagery. Raw tally confusion matrix of land cover and calculated accuracies of the classification scheme are provided. Agreement is shown along the diagonal (in bold) and discrepancies are shown in off-diagonals. Overall accuracy denoted with $(*)$; kappa coefficient $=0.8$.

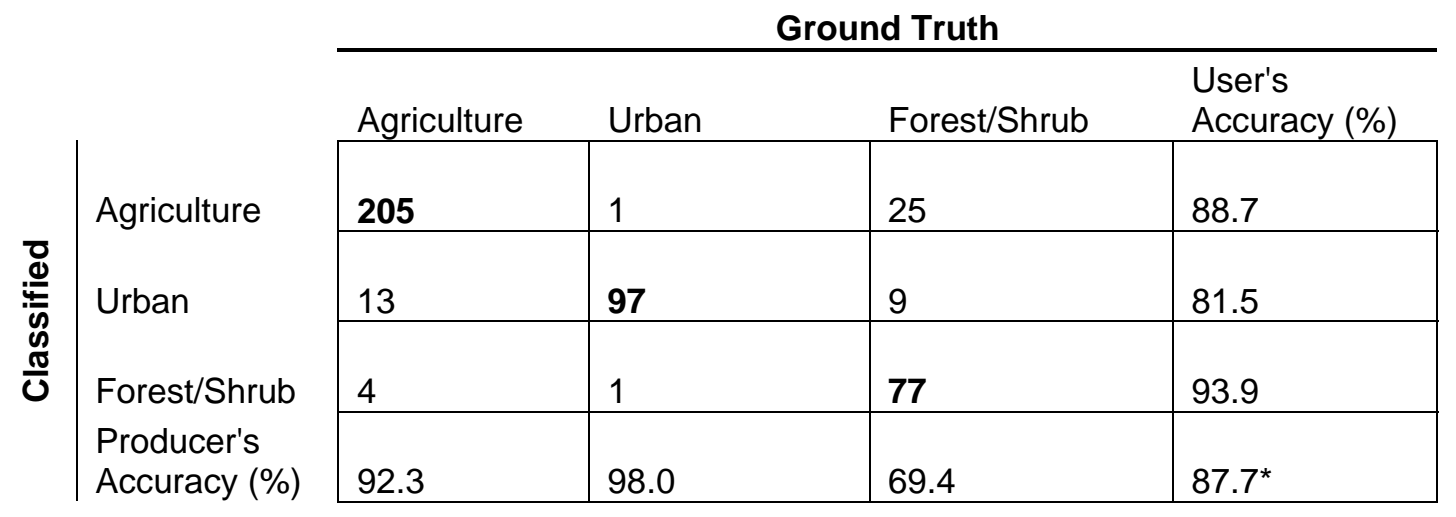


Table 2-4: Changes in reach type for all reaches $(\mathrm{N}=424)$ in the Wenatchee system from 1949 to 2006: (A) Raw tally matrix of instances of change, (B) Probability matrix (0.0 - 1.0). Dynamics of transitioning reaches (in bold) are examined further in Table 5.

A. 2006

\begin{tabular}{|c|c|c|c|c|c|}
\hline & Straight & Meandering & $\begin{array}{l}\text { Island } \\
\text { Braided }\end{array}$ & Pool/Riffle & Plane Bed \\
\hline Straight & 222 & 3 & 20 & - & - \\
\hline Meandering & 18 & 49 & 7 & - & - \\
\hline $\begin{array}{l}\text { Island } \\
\text { Braided }\end{array}$ & 10 & 1 & 13 & - & - \\
\hline Pool/Riffle & - & - & - & 9 & 8 \\
\hline Plane Bed & - & - & - & 1 & 63 \\
\hline
\end{tabular}

B. 2006

\begin{tabular}{|c|c|c|c|c|c|}
\hline \multirow[b]{2}{*}{ Straight } & Straight & Meandering & $\begin{array}{l}\text { Island } \\
\text { Braided }\end{array}$ & Pool/Riffle & Plane Bed \\
\hline & 0.91 & 0.01 & 0.08 & - & - \\
\hline Meandering & 0.24 & 0.66 & 0.09 & - & - \\
\hline $\begin{array}{l}\text { Island } \\
\text { Braided }\end{array}$ & 0.42 & 0.04 & 0.54 & - & - \\
\hline Pool/Riffle & - & - & - & 0.53 & 0.47 \\
\hline Plane Bed & - & - & - & 0.02 & 0.98 \\
\hline
\end{tabular}


Table 2-5: Comparison of mean characteristics in transitioning reaches (identified in Table 4) compared to reaches which remained unchanged from 1949 to $2006(\mathrm{~A}-\mathrm{C})$. Differences between 1949 and 2006 mean values as well as the change over time have also been compared. Significant p-values have been highlighted (in bold).

\section{A1. Temporal Changes in Characteristics of Meandering Reaches circa 1949}

\begin{tabular}{|c|c|c|c|c|c|c|c|c|}
\hline \multirow[b]{3}{*}{$\begin{array}{l}\text { Mean Reach-Level } \\
\text { Characteristics }\end{array}$} & \multicolumn{4}{|c|}{$\begin{array}{c}\text { Transitioning Reaches }(n=18) \\
\text { Transitioned to Straight as of } 2006\end{array}$} & \multicolumn{4}{|c|}{$\begin{array}{l}\text { Non-Transitioning Reaches }(n=49) \\
\text { Remained Meandering as of } 2006\end{array}$} \\
\hline & \multirow{2}{*}{$\begin{array}{l}\text { Initial } \\
\text { Conditions } \\
(1949)\end{array}$} & \multirow{2}{*}{$\begin{array}{l}\text { Ending } \\
\text { Conditions } \\
(2006)\end{array}$} & \multicolumn{2}{|c|}{ Comparison Over Time } & \multirow{2}{*}{$\begin{array}{l}\text { Initial } \\
\text { Conditions } \\
(1949)\end{array}$} & \multirow{2}{*}{$\begin{array}{l}\text { Ending } \\
\text { Conditions } \\
(2006)\end{array}$} & \multicolumn{2}{|c|}{ Comparison Over Time } \\
\hline & & & $\begin{array}{l}\text { Mean } \\
\text { Change }\end{array}$ & Significance & & & $\begin{array}{l}\text { Mean } \\
\text { Change }\end{array}$ & Significance \\
\hline Sinuosity & 1.58 & 1.32 & -0.26 & 0.0003 & 2.04 & 1.92 & -0.12 & 0.6602 \\
\hline Reach Length (m) & 834.27 & 689.96 & -144.32 & $<0.0001$ & 844.09 & 796.20 & -47.89 & 0.3553 \\
\hline \multicolumn{9}{|l|}{ Anthropogenic Land Cover } \\
\hline$\%$ of Floodplain & 1.14 & 4.34 & 3.21 & 0.0009 & 7.42 & 9.03 & 1.62 & 0.0084 \\
\hline$\%$ of Riparian Area & 0.84 & 3.23 & 2.39 & 0.0327 & 5.70 & 7.55 & 1.85 & 0.0305 \\
\hline
\end{tabular}

\section{A2. Comparison of Characteristics in Transitioning and Non-Transitioning Meandering Reaches (n=67)}

\begin{tabular}{|c|c|c|c|}
\hline & $\begin{array}{l}\text { Comparison of Initial } \\
\text { Conditions (1949) }\end{array}$ & $\begin{array}{l}\text { Comparison of Ending } \\
\text { Conditions (2006) }\end{array}$ & Change Over Time \\
\hline $\begin{array}{l}\text { Mean Reach-Level } \\
\text { Characteristics }\end{array}$ & Significance & Significance & Significance \\
\hline Sinuosity & 0.0003 & $<0.0001$ & 0.0012 \\
\hline Reach Length (m) & 0.9211 & 0.0363 & $<0.0001$ \\
\hline Anthropogenic Land Col & & & \\
\hline$\%$ of Floodplain & 0.8200 & 0.8538 & 0.1252 \\
\hline$\%$ of Riparian Area & 0.6060 & 0.9184 & 0.4676 \\
\hline
\end{tabular}


B1. Temporal Changes in Characteristics of Island Braided Reaches circa 1949

\begin{tabular}{|c|c|c|c|c|c|c|c|c|}
\hline \multirow[b]{3}{*}{$\begin{array}{l}\text { Mean Reach-Level } \\
\text { Characteristics }\end{array}$} & \multicolumn{4}{|c|}{$\begin{array}{l}\text { Transitioning Reaches }(n=10) \\
\text { Transitioned to Straight as of } 2006\end{array}$} & \multicolumn{4}{|c|}{$\begin{array}{l}\text { Non-Transitioning Reaches }(n=13) \\
\text { Remained Island Braided as of } 2006\end{array}$} \\
\hline & \multirow{2}{*}{$\begin{array}{l}\text { Initial } \\
\text { Conditions } \\
\text { (1949) }\end{array}$} & \multirow{2}{*}{$\begin{array}{l}\text { Ending } \\
\text { Conditions } \\
\text { (2006) }\end{array}$} & \multicolumn{2}{|c|}{ Comparison Over Time } & \multirow{2}{*}{$\begin{array}{l}\text { Initial } \\
\text { Conditions } \\
(1949)\end{array}$} & \multirow{2}{*}{$\begin{array}{l}\text { Ending } \\
\text { Conditions } \\
(2006)\end{array}$} & \multicolumn{2}{|c|}{ Comparison Over Time } \\
\hline & & & $\begin{array}{l}\text { Mean } \\
\text { Change }\end{array}$ & Significance & & & $\begin{array}{l}\text { Mean } \\
\text { Change }\end{array}$ & Significance \\
\hline Sinuosity & 1.20 & 1.18 & -0.01 & 0.4961 & 1.58 & 1.57 & 0.00 & 0.8008 \\
\hline Reach Length (m) & 921.03 & 910.99 & -10.04 & 0.0481 & 1483.75 & 1481.92 & -1.84 & 0.9642 \\
\hline \multicolumn{9}{|c|}{ Anthropogenic Land Cover } \\
\hline$\%$ of Floodplain & 28.00 & 30.38 & 2.38 & 0.0078 & 61.00 & 64.48 & 3.47 & 0.1909 \\
\hline$\%$ of Riparian Area & 19.32 & 22.65 & 3.33 & 0.0234 & 47.30 & 55.85 & 8.56 & 0.0574 \\
\hline \multicolumn{9}{|l|}{ Channel Habitat } \\
\hline $\begin{array}{l}\text { Vegetated Island } \\
\left(\mathrm{m}^{2} / \text { reach }\right)\end{array}$ & 4.93 & 1.78 & -3.16 & 0.0273 & 15.09 & 11.29 & -3.80 & 0.3757 \\
\hline
\end{tabular}

B2. Comparison of Characteristics in Transitioning and Non-Transitioning Island Braided Reaches (n=23)

\begin{tabular}{|c|c|c|c|}
\hline $\begin{array}{l}\text { Mean Reach-Level } \\
\text { Characteristics }\end{array}$ & $\begin{array}{l}\text { Comparison of Initial } \\
\text { Conditions (1949) } \\
\text { Significance }\end{array}$ & $\begin{array}{l}\text { Comparison of Ending } \\
\text { Conditions (2006) } \\
\text { Significance }\end{array}$ & $\begin{array}{l}\text { Change Over Time } \\
\text { Significance }\end{array}$ \\
\hline Sinuosity & 0.5767 & 0.4568 & 0.4568 \\
\hline Reach Length (m) & 0.0029 & 0.0043 & 0.4951 \\
\hline \multicolumn{4}{|c|}{ Anthropogenic Land Cover } \\
\hline$\%$ of Floodplain & 0.0217 & 0.0255 & 0.8524 \\
\hline$\%$ of Riparian Area & 0.0349 & 0.0407 & 0.6197 \\
\hline \multicolumn{4}{|l|}{ Channel Habitat } \\
\hline $\begin{array}{l}\text { Vegetated Island } \\
\left(\mathrm{m}^{2} / \text { reach }\right)\end{array}$ & 0.5767 & 0.0075 & 0.3211 \\
\hline
\end{tabular}


C1. Temporal Changes in Characteristics of Island Braided Reaches, circa 2006

\begin{tabular}{|c|c|c|c|c|c|c|c|c|}
\hline \multirow[b]{3}{*}{$\begin{array}{l}\text { Mean Reach-Level } \\
\text { Characteristics }\end{array}$} & \multicolumn{4}{|c|}{$\begin{array}{l}\text { Transitioning Reaches }(n=20) \\
\text { Transitioned from Straight in } 1949\end{array}$} & \multicolumn{4}{|c|}{$\begin{array}{l}\text { Non-Transitioning Reaches }(n=13) \\
\text { Remained Island Braided from } 1949\end{array}$} \\
\hline & \multirow{2}{*}{$\begin{array}{l}\text { Initial } \\
\text { Conditions } \\
(1949) \\
\end{array}$} & \multirow{2}{*}{$\begin{array}{l}\text { Ending } \\
\text { Conditions } \\
\text { (2006) }\end{array}$} & \multicolumn{2}{|c|}{ Comparison Over Time } & \multirow{2}{*}{$\begin{array}{l}\text { Initial } \\
\text { Conditions } \\
\text { (1949) }\end{array}$} & \multirow{2}{*}{$\begin{array}{l}\text { Ending } \\
\text { Conditions } \\
(2006) \\
\end{array}$} & \multicolumn{2}{|c|}{ Comparison Over Time } \\
\hline & & & $\begin{array}{l}\text { Mean } \\
\text { Change }\end{array}$ & Significance & & & $\begin{array}{l}\text { Mean } \\
\text { Change }\end{array}$ & Significance \\
\hline Sinuosity & 1.21 & 1.24 & 0.04 & 0.4468 & 1.58 & 1.57 & 0.00 & 0.8008 \\
\hline Reach Length (m) & 647.00 & 658.99 & 11.99 & 0.5958 & 1483.75 & 1481.92 & -1.84 & 0.9642 \\
\hline \multicolumn{9}{|c|}{ Anthropogenic Land Cover } \\
\hline$\%$ of Floodplain & 0.72 & 3.35 & 2.63 & 0.0038 & 61.00 & 64.48 & 3.47 & 0.1909 \\
\hline$\%$ of Riparian Area & 0.88 & 3.13 & 2.25 & 0.0131 & 47.30 & 55.85 & 8.56 & 0.0574 \\
\hline
\end{tabular}

\section{C2. Comparison of Characteristics in Transitioning and Non-Transitioning Island Braided Reaches (n=33)}

\begin{tabular}{lr|r|r}
\hline & $\begin{array}{l}\text { Comparison of Initial } \\
\text { Conditions (1949) }\end{array}$ & $\begin{array}{l}\text { Comparison of Ending } \\
\text { Conditions (2006) }\end{array}$ & Change Over Time \\
Mean Reach-Level & Significance & Significance & Significance \\
\hline Characteristics & 0.4839 & 0.7841 & 0.9413 \\
Reach Length (m) & $<\mathbf{0 . 0 0 0 1}$ & $<0.0001$ & 0.5555 \\
Anthropogenic Land Cover & $<0.0001$ & $<0.0001$ & 0.9412 \\
\% of Floodplain & $\mathbf{0 . 0 0 0 2}$ & $\mathbf{0 . 0 0 0 3}$ & 0.3762 \\
\% of Riparian Area & & & \\
\hline
\end{tabular}


Table 2-6: Changes in mean area and number of habitat features at the reach level. Reaches were included only if they contained a given habitat feature in one or both years. Significant change highlighted in bold.

\begin{tabular}{|c|c|c|c|c|c|}
\hline \multirow[b]{2}{*}{ Habitat Features (mean) } & \multirow{2}{*}{$\begin{array}{l}\text { Number of } \\
\text { Reaches } \\
\text { (n) }\end{array}$} & \multirow{2}{*}{$\begin{array}{l}\text { Initial } \\
\text { Condition } \\
(1949)\end{array}$} & \multirow{2}{*}{$\begin{array}{l}\text { Ending } \\
\text { Condition } \\
\text { (2006) }\end{array}$} & \multicolumn{2}{|c|}{ Comparison over time } \\
\hline & & & & $\begin{array}{l}\text { Mean } \\
\text { Change }\end{array}$ & Significance \\
\hline \multicolumn{6}{|l|}{ Area (ha/reach) } \\
\hline Slow/Stagnant Channels & 55 & 0.016 & 0.013 & -0.0031 & 0.7597 \\
\hline Dry Channels & 59 & 0.017 & 0.011 & -0.0058 & 0.0168 \\
\hline Pond/Wetland & 75 & 0.010 & 0.013 & 0.0032 & 0.3013 \\
\hline Vegetated Island & 78 & 4.402 & 5.168 & 0.7666 & 0.0220 \\
\hline \multicolumn{6}{|l|}{ Number of Features per Reach } \\
\hline Slow/Stagnant Channels & 55 & 2.27E-06 & 2.57E-06 & 2.93E-07 & 0.5733 \\
\hline Dry Channels & 59 & $3.42 \mathrm{E}-06$ & 2.47E-06 & $-9.54 \mathrm{E}-07$ & 0.0282 \\
\hline Pond/Wetland & 75 & $2.72 \mathrm{E}-06$ & $3.15 E-06$ & 4.24E-07 & 0.1035 \\
\hline Vegetated Island & 78 & 7.80E-04 & 1.67E-03 & 8.89E-04 & $<0.0001$ \\
\hline
\end{tabular}


Table 2-7: Comparison of mean area and mean number of floodplain and channel habitat features for floodplains with (A) higher and (B) lower anthropogenic modification to the floodplain (as described in Figure 6). Significant change highlighted in bold.

\begin{tabular}{|c|c|c|c|c|c|c|c|c|c|}
\hline & \multirow{3}{*}{$\begin{array}{l}\text { Number of } \\
\text { Reaches } \\
\text { (n) }\end{array}$} & \multicolumn{4}{|c|}{ Mean Area of Habitat Features } & \multicolumn{4}{|c|}{ Mean Number of Habitat Features } \\
\hline & & \multirow{2}{*}{$\begin{array}{l}\text { Initial } \\
\text { Mean } \\
(1949)\end{array}$} & \multirow{2}{*}{$\begin{array}{l}\text { Ending } \\
\text { Mean } \\
(2006) \\
\end{array}$} & \multicolumn{2}{|c|}{ Comparison over time } & \multirow{2}{*}{$\begin{array}{l}\text { Initial } \\
\text { Mean } \\
(1949)\end{array}$} & \multirow{2}{*}{$\begin{array}{l}\text { Ending } \\
\text { Mean } \\
(2006)\end{array}$} & \multicolumn{2}{|c|}{ Comparison over time } \\
\hline & & & & $\begin{array}{l}\text { Mean } \\
\text { Change }\end{array}$ & Significance & & & $\begin{array}{l}\text { Mean } \\
\text { Change }\end{array}$ & Significance \\
\hline \multicolumn{10}{|l|}{ Highly Modified Floodplains } \\
\hline Slow/Stagnant Channels & 18 & 0.012 & 0.013 & 0.001 & 0.3247 & 1.19E-06 & 2.59E-06 & $1.40 \mathrm{E}-06$ & 0.0519 \\
\hline Dry Channels & 17 & 0.010 & 0.010 & 0.000 & 0.8900 & 1.77E-06 & 1.96E-06 & 1.93E-07 & 0.8926 \\
\hline Pond/Wetland & 10 & 0.014 & 0.020 & 0.006 & 0.0840 & 5.56E-07 & 4.18E-06 & $3.62 E-06$ & 0.0039 \\
\hline Vegetated Island & 41 & 7.119 & 7.425 & 0.306 & 0.3212 & $6.49 \mathrm{E}-04$ & $1.35 \mathrm{E}-03$ & 7.05E-04 & $<0.0001$ \\
\hline \multicolumn{10}{|l|}{ Less Modified Floodplains } \\
\hline Slow/Stagnant Channels & 37 & 0.018 & 0.013 & -0.005 & 0.3766 & 2.80E-06 & $2.55 E-06$ & $-2.45 E-07$ & 0.7202 \\
\hline Dry Channels & 42 & 0.020 & 0.012 & -0.008 & 0.0088 & 4.09E-06 & 2.67E-06 & $-1.42 E-06$ & 0.0106 \\
\hline Pond/Wetland & 65 & 0.009 & 0.012 & 0.003 & 0.6163 & 3.06E-06 & 2.99E-06 & $-6.86 E-08$ & 0.4181 \\
\hline Vegetated Island & 37 & 1.390 & 2.667 & 1.277 & 0.0376 & $9.25 E-04$ & $2.02 \mathrm{E}-03$ & 1.09E-03 & 0.0249 \\
\hline
\end{tabular}




\section{Figures}

Figure 2.1: The Wenatchee River Watershed, Washington, USA.

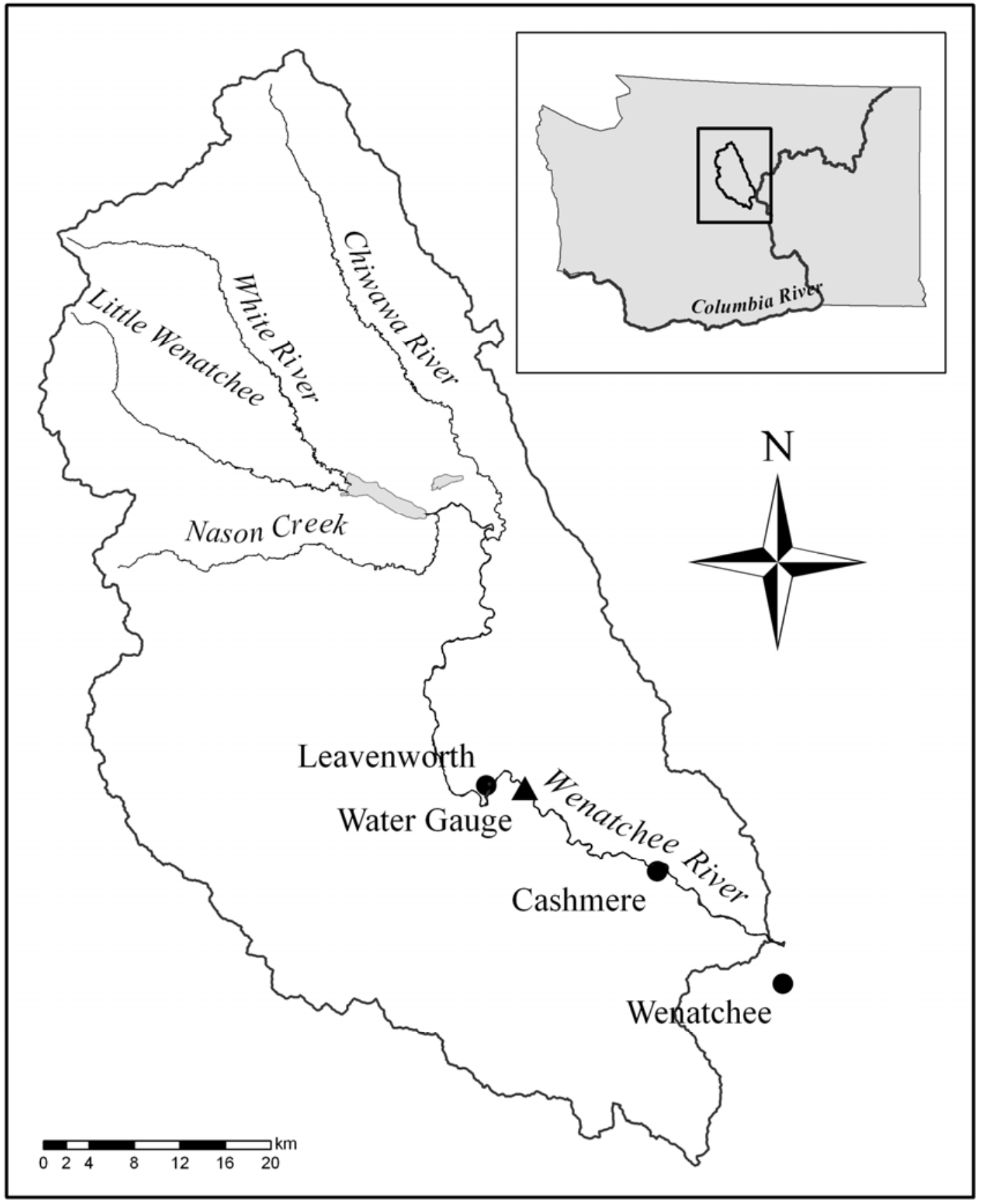


Figure 2.2: Monthly median historic (1949) and modern (2006) stream discharge as well as median monthly discharge and range (maximum and minimum discharge) spanning 1929 - 2007 for of the Wenatchee River below Leavenworth, WA (Figure 1).

Modern orthophotos acquired in July - August 2006; historic imagery acquired September 3 - 21, 1949.

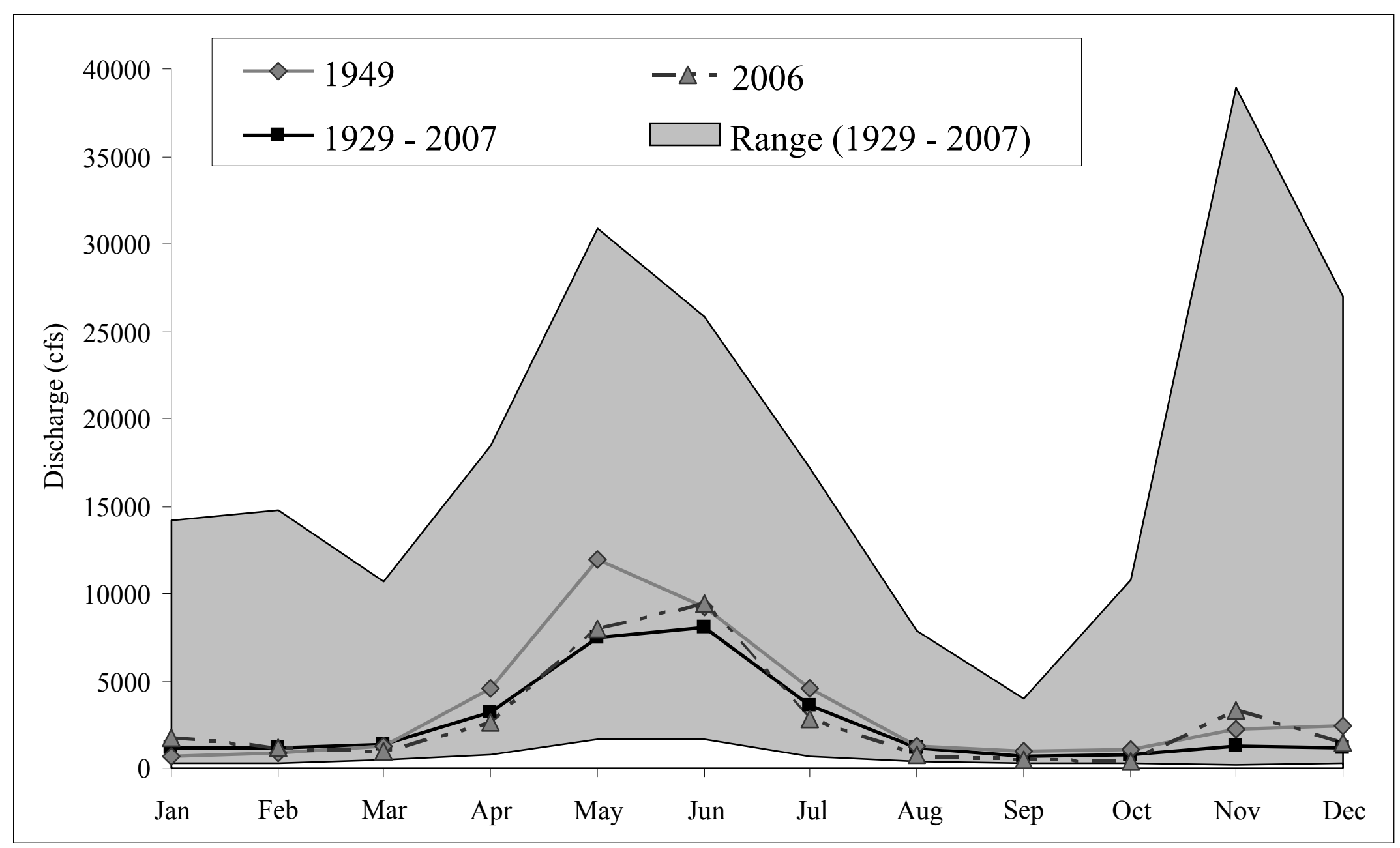


Figure 2.3: A comparison of coarse and fine scale landscape views. (A) Coarse scale showing general land cover (agriculture, urban forest/shrub and road). (B) Fine scale showing floodplain habitat features (e.g., slow/stagnant channels).
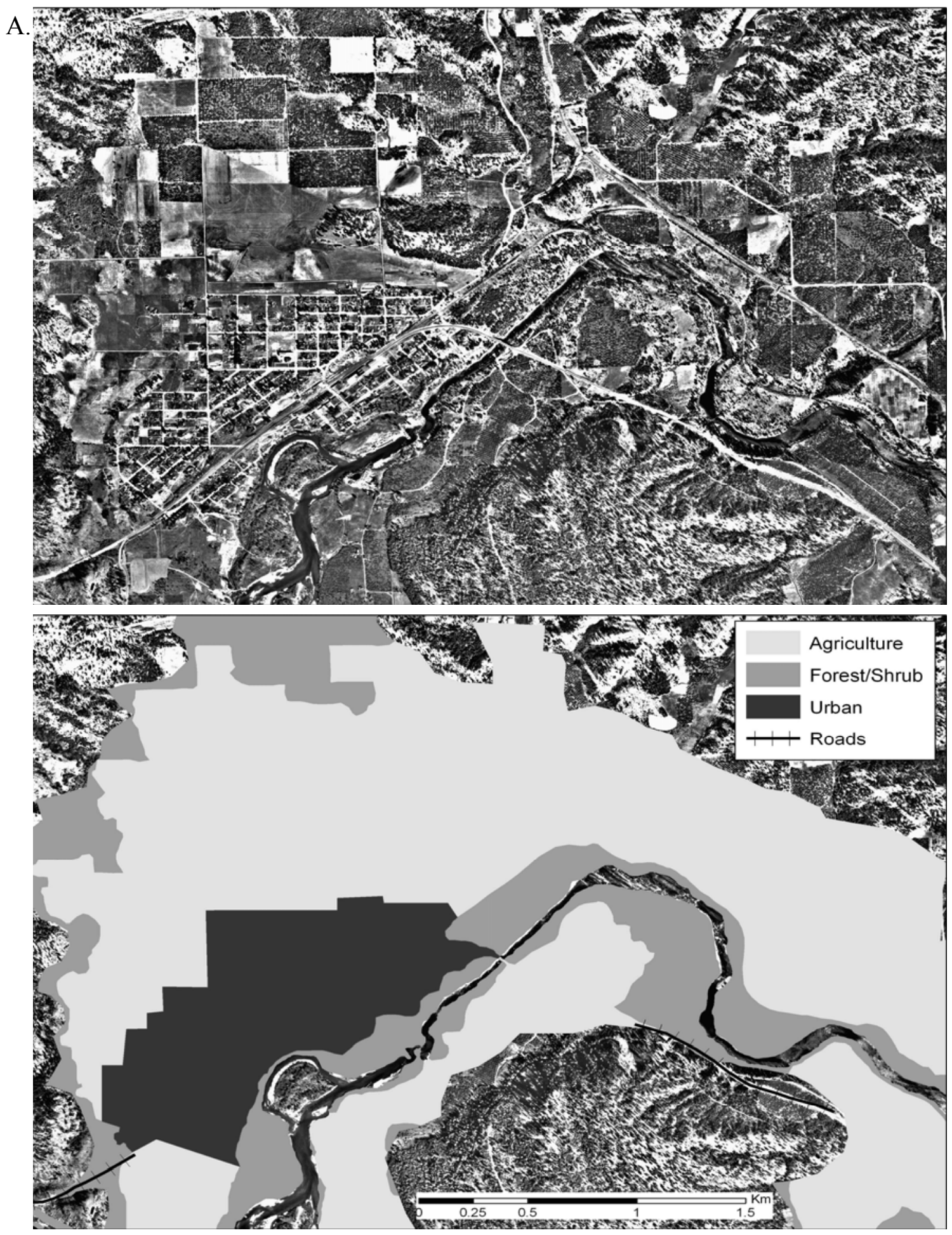

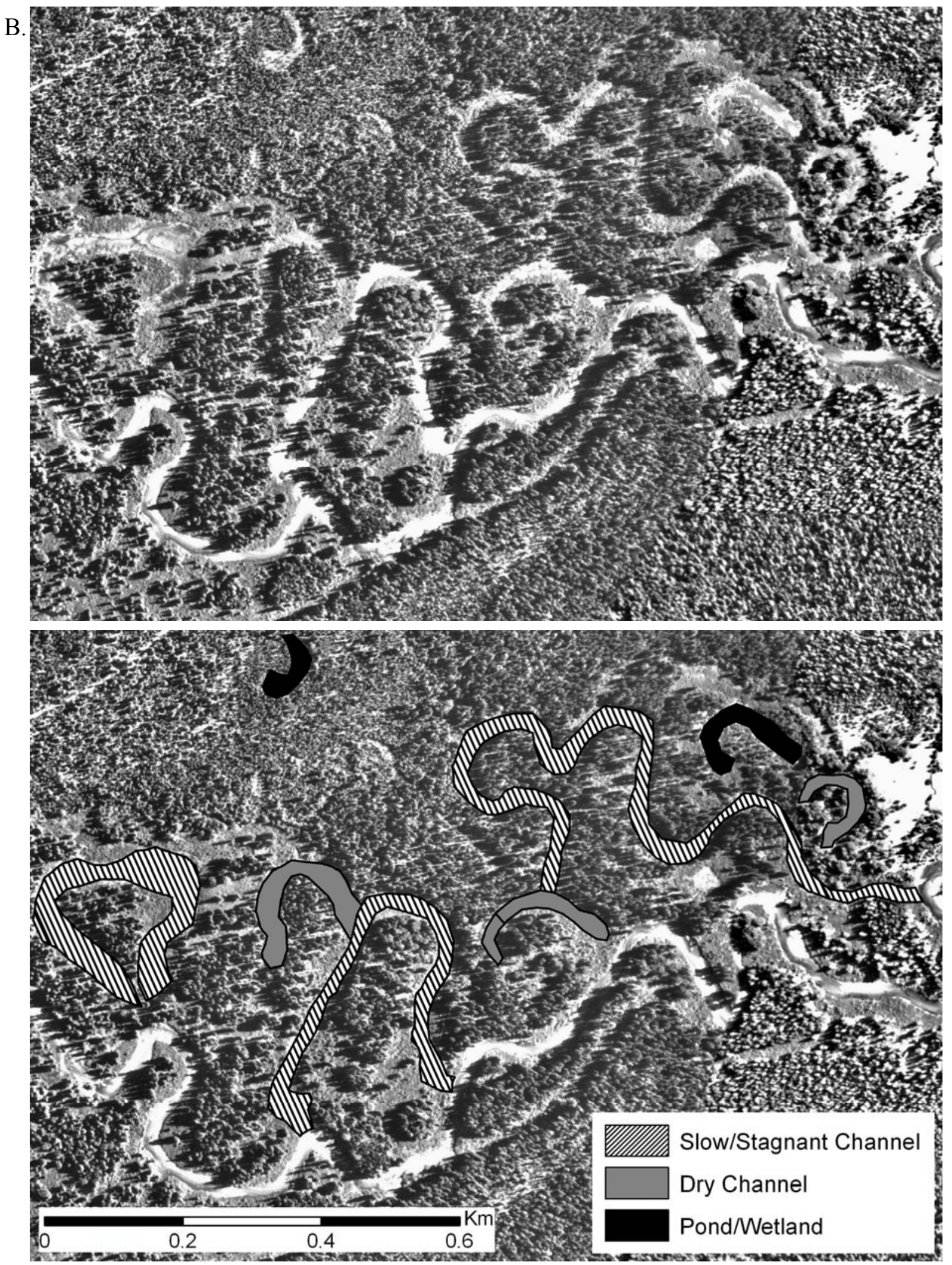
Figure 2.4: (A) A subsample of the GPS points used to assess the accuracy of the modern general land cover classification scheme in a confusion matrix (Table 3). (B) A subsample of the 3,000 randomly generated points used to create the transition matrix (Table 2) of the general land cover classification scheme.

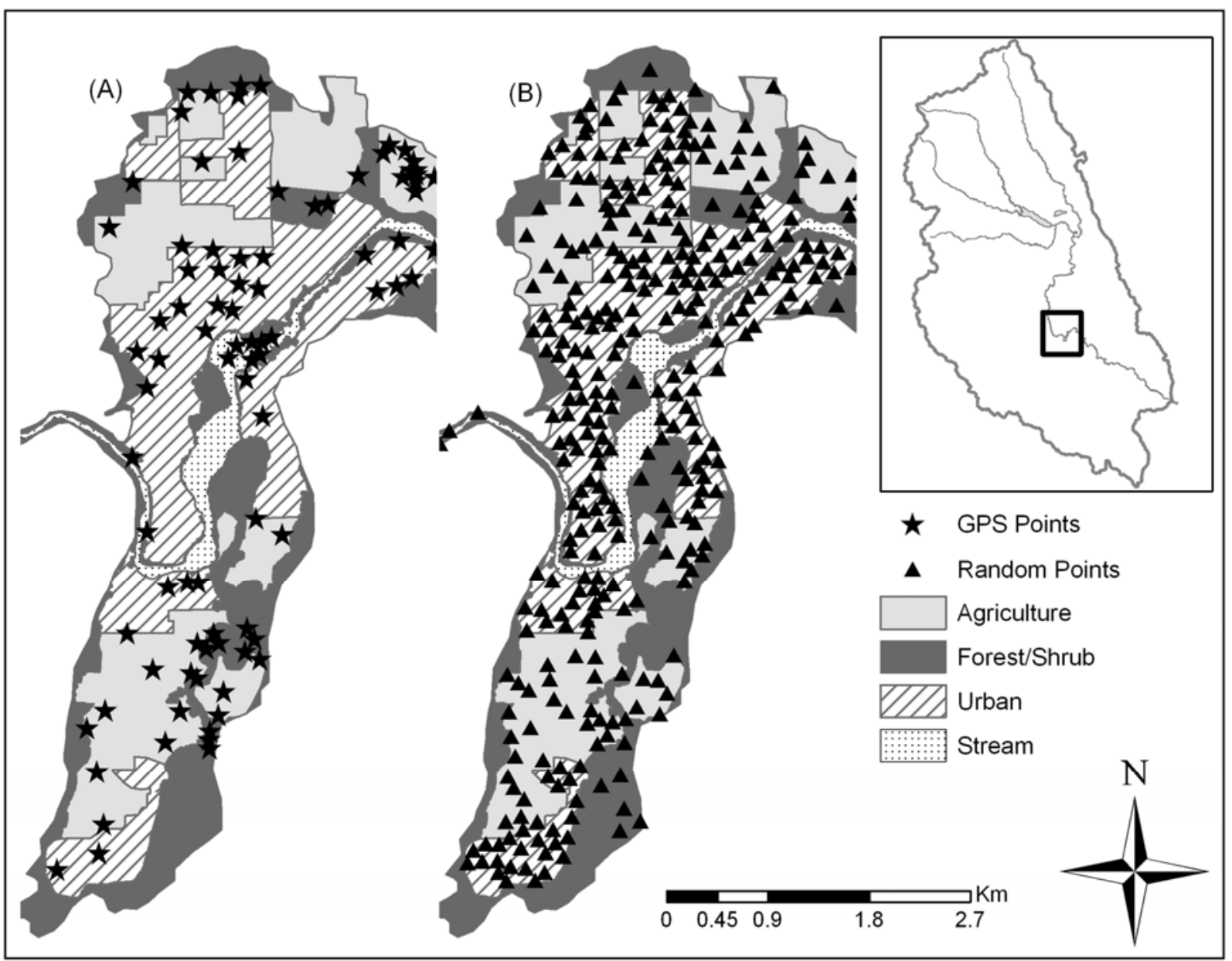


Figure 2.5: Changes in general land cover types within (A) floodplain and (B) riparian area of the Wenatchee system (Wenatchee, Chiwawa, White and Little Wenatchee Rivers and Nason Creek).

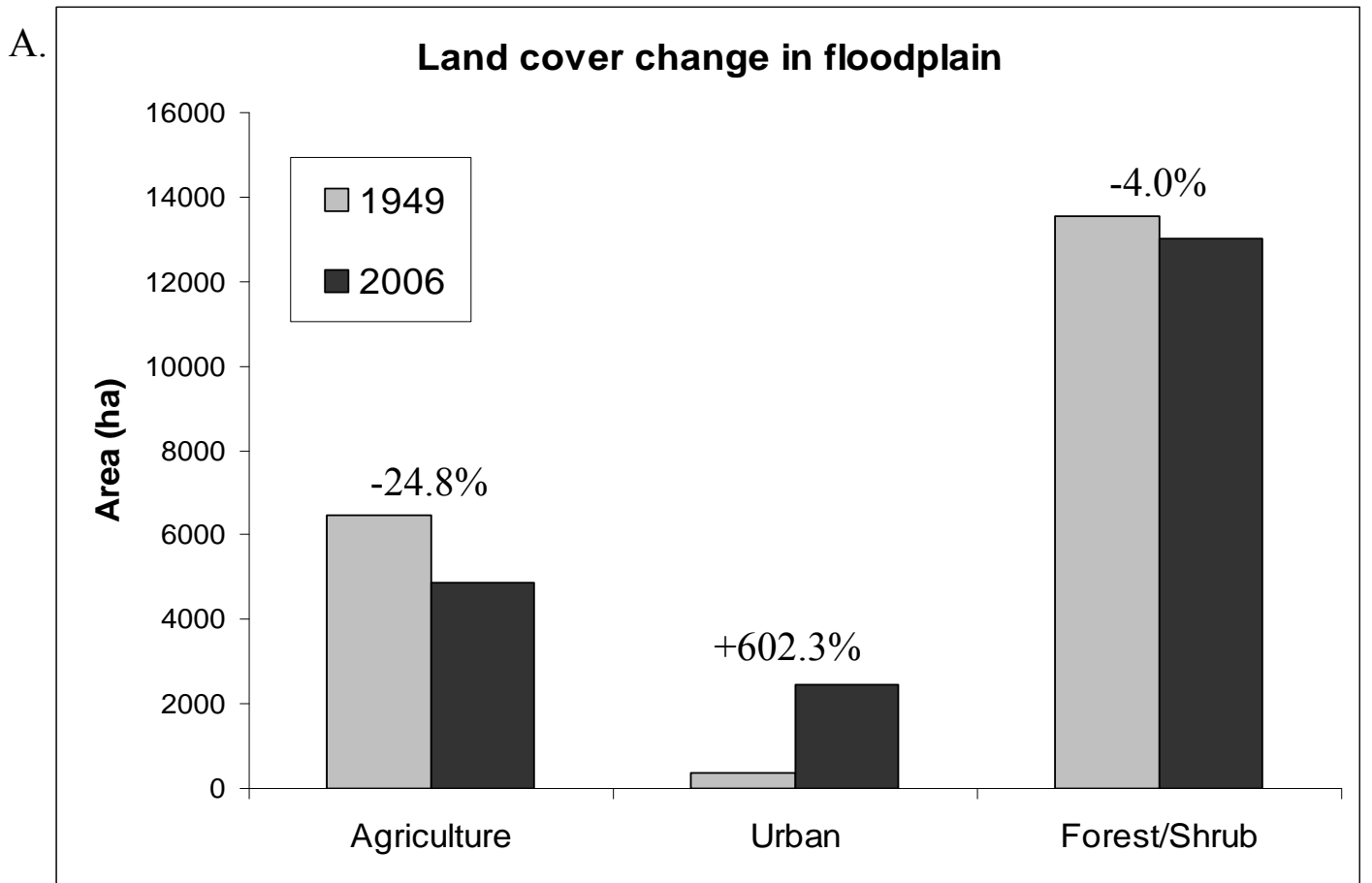

B.

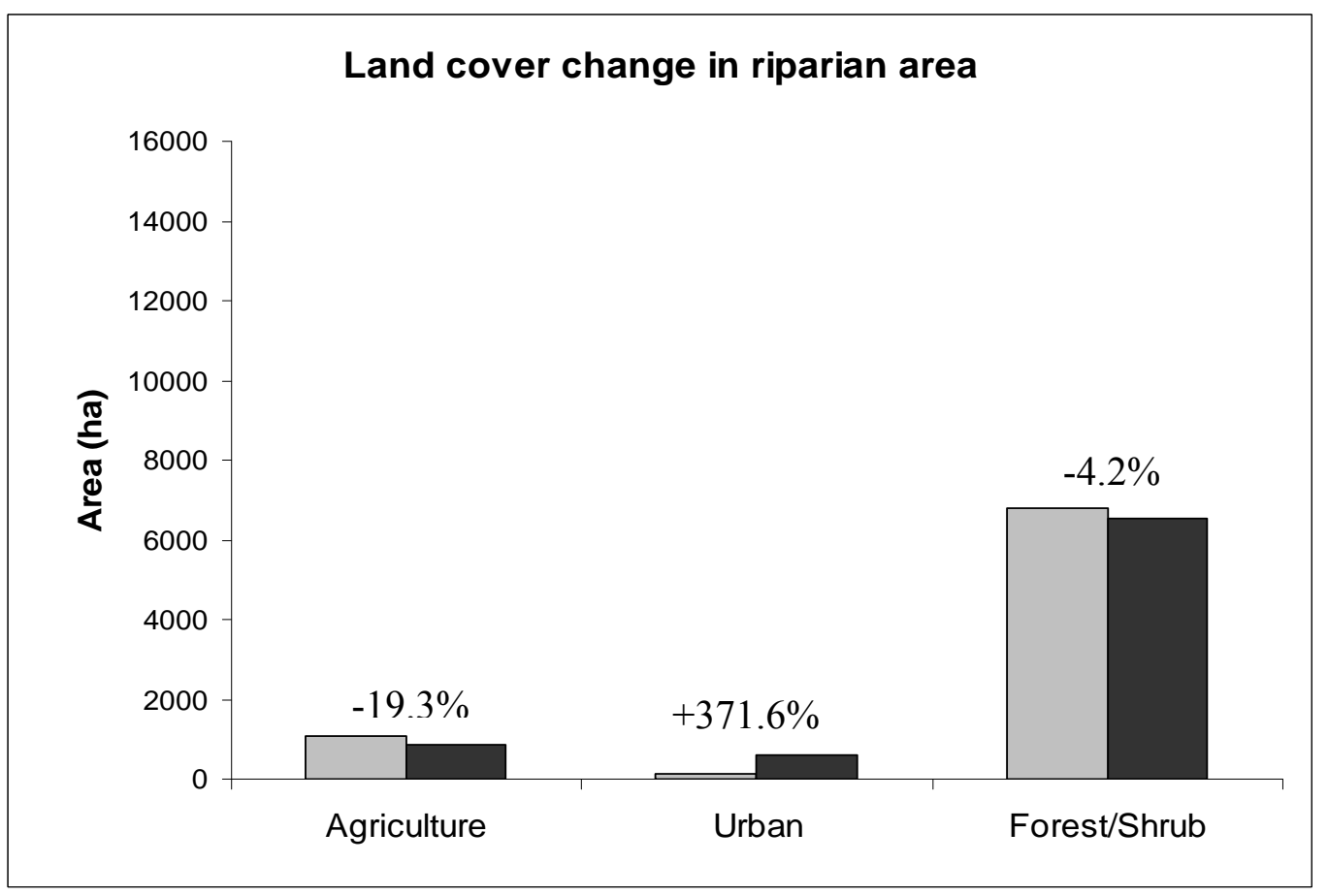


Figure 2.6: Percent of (A) floodplain and (B) riparian area modified by anthropogenic development (i.e., urban, agriculture and roads) for the Wenatchee system. Data from 1949 displayed in the left column and 2006 in the right column for each pairing.

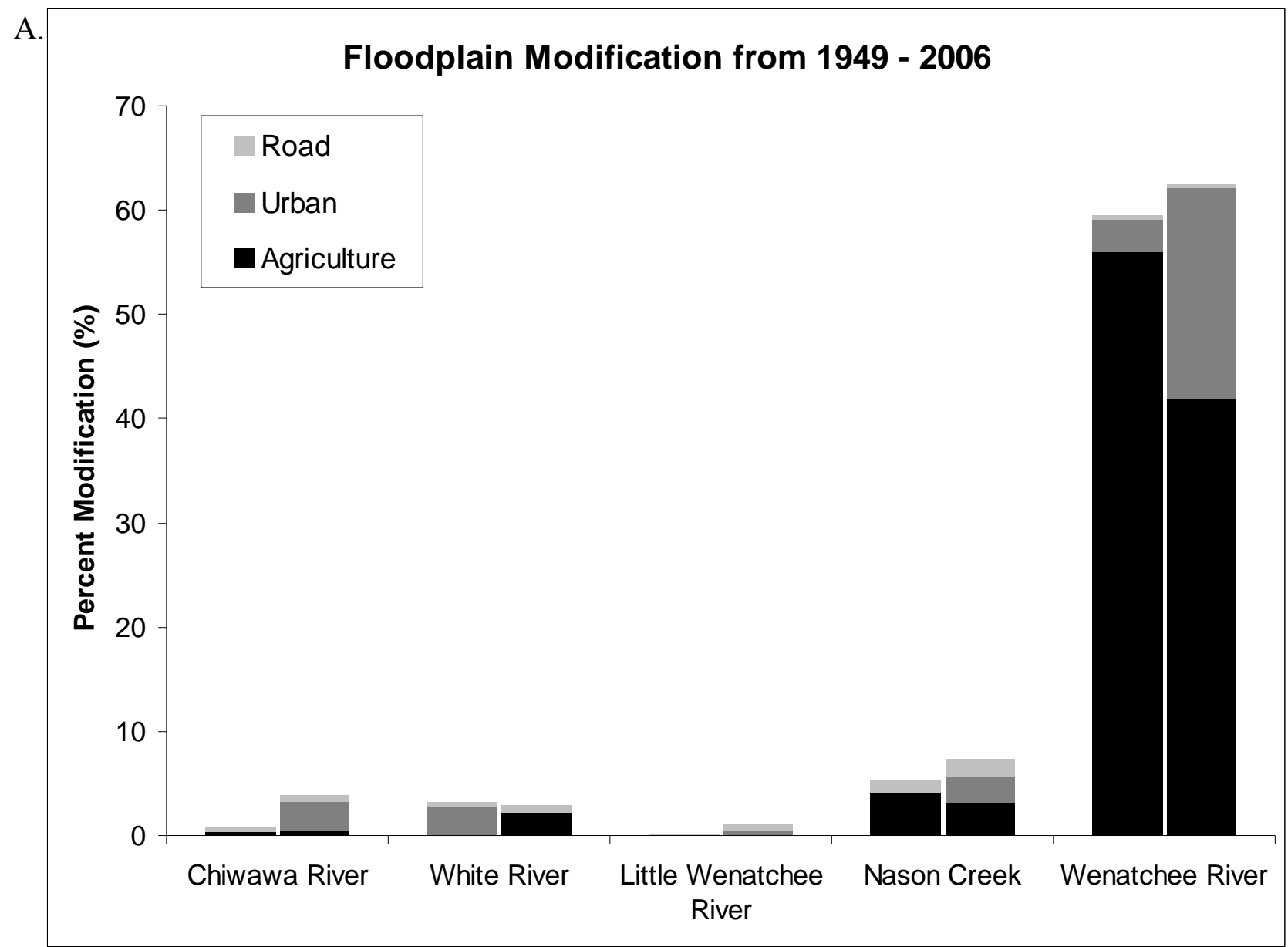


B.

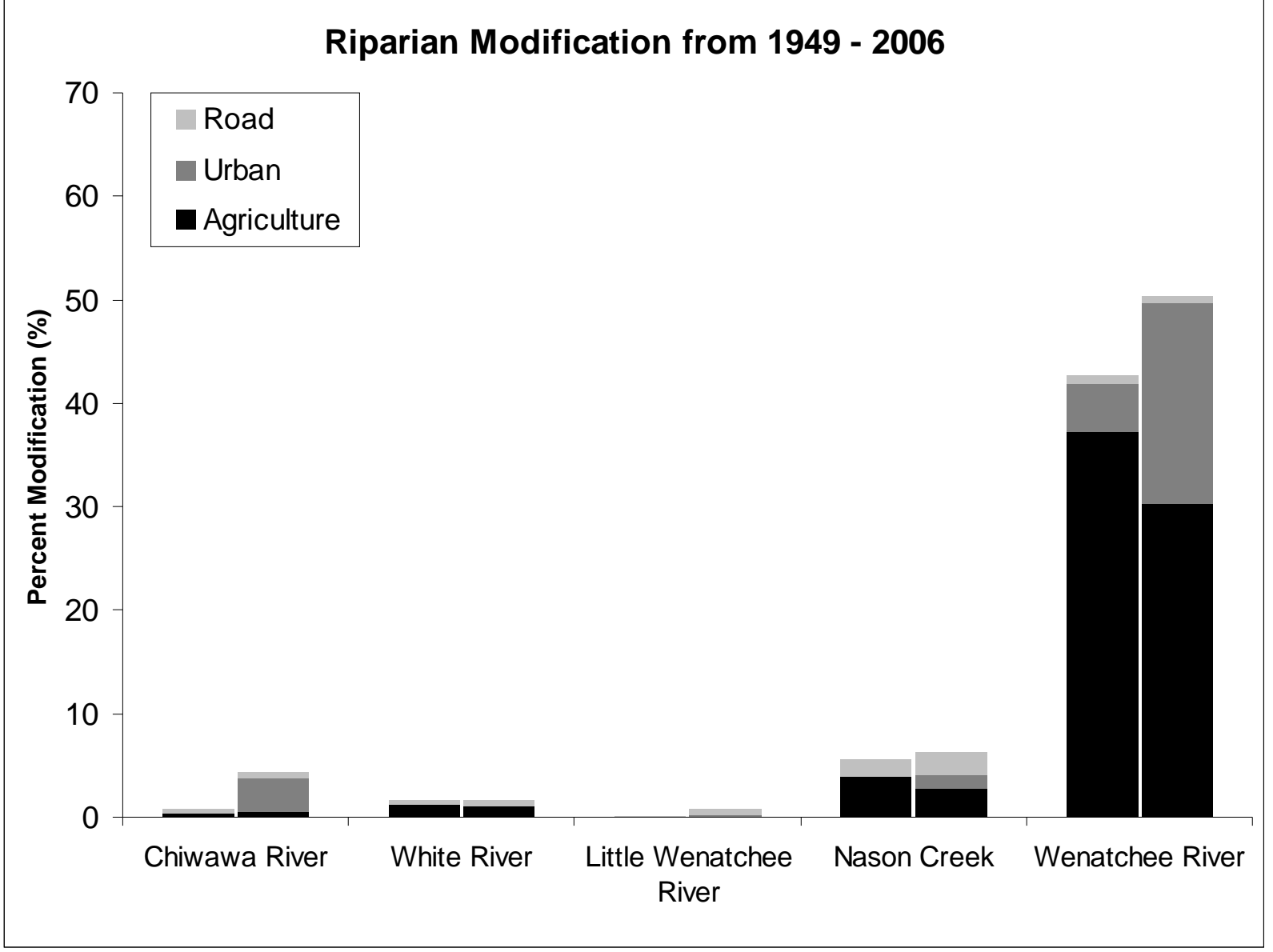


Figure 2.7: Changes in relative abundance of different reach types for all 424 reaches within in the Wenatchee system.

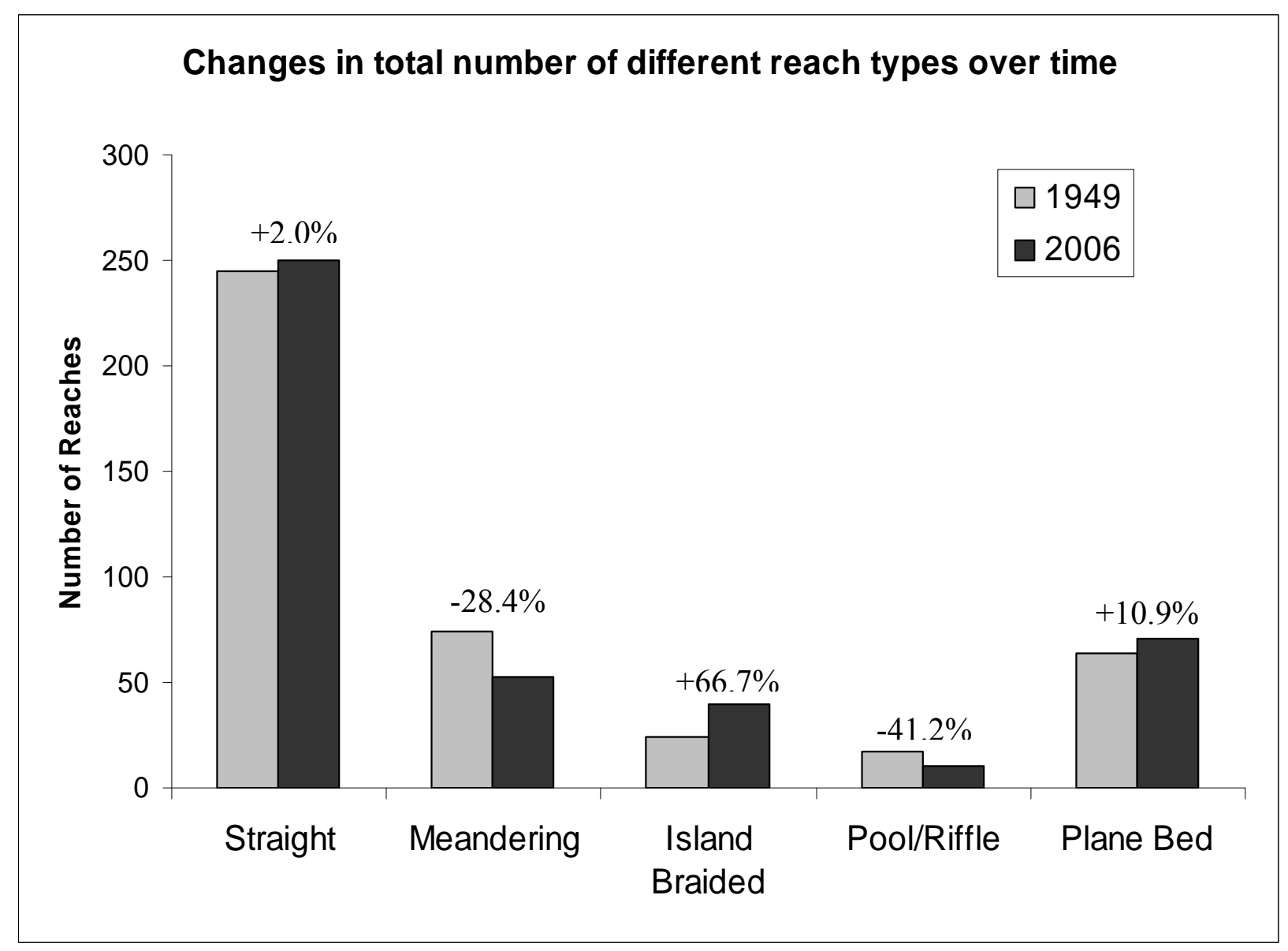


Figure 2.8: Changes in (A) total area and (B) number of floodplain and channel habitat features observed within the Wenatchee system. Percent change over time displayed above each set of paired bars.

A.

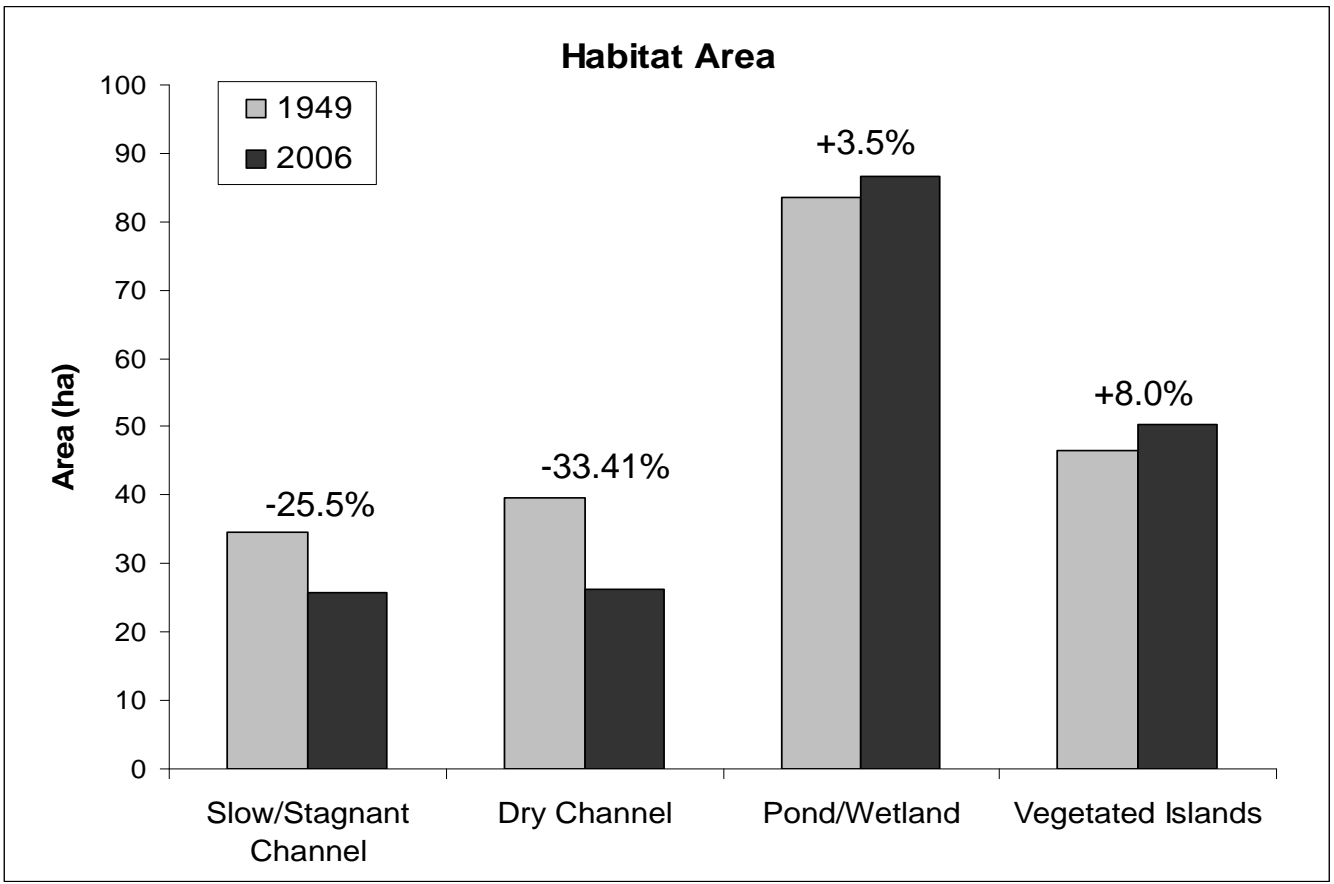

B.

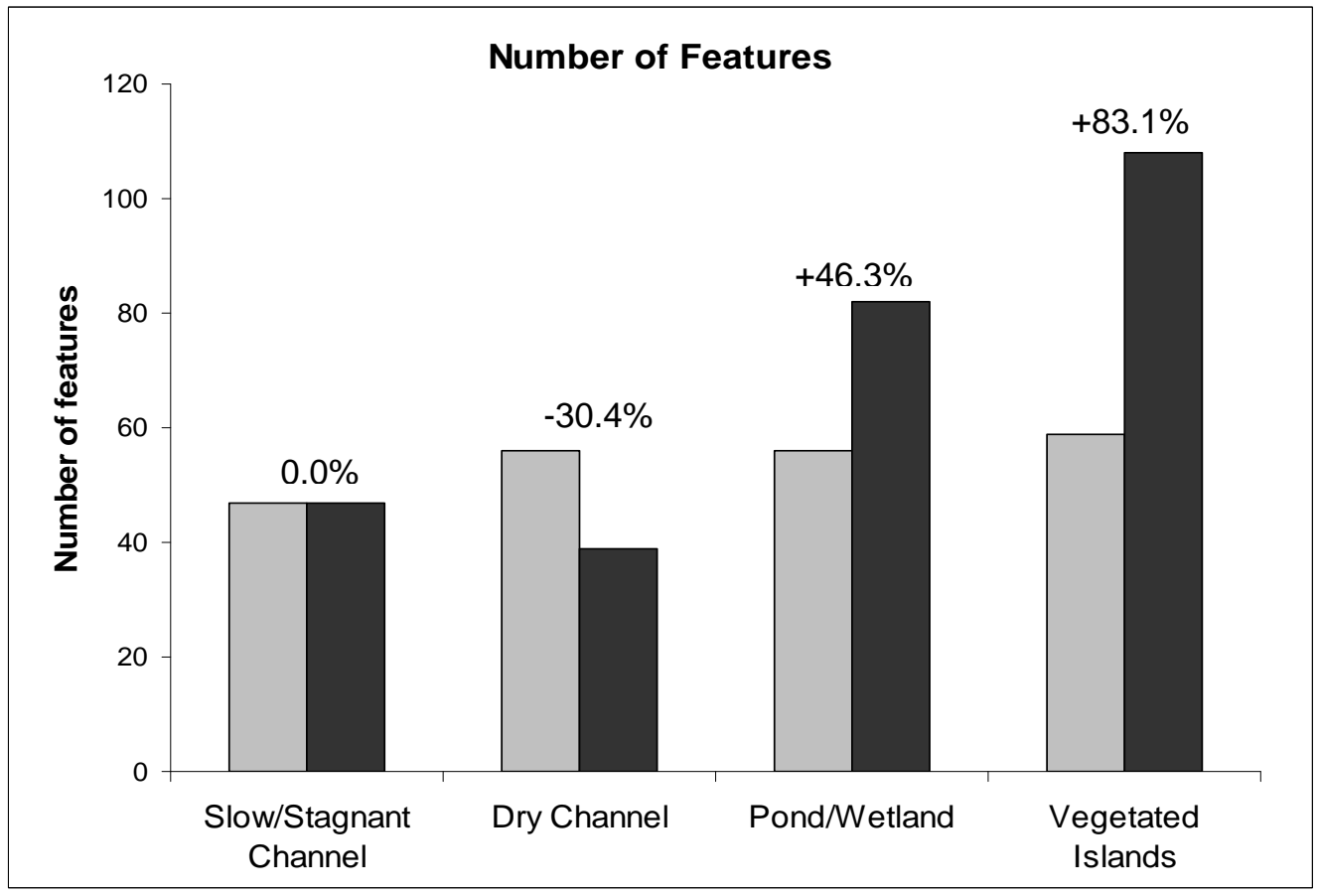


Figure 2.9: Impact of floodplain land cover modification (i.e., agriculture, urban and roads) on total (A) area and (B) number of floodplain and channel habitat features from 1949 to 2006. As shown in Figure 6, Wenatchee River and Nason Creek represent rivers with highly modified floodplains, whereas Chiwawa, White and Little Wenatchee Rivers represent rivers with less modified floodplains.

A.

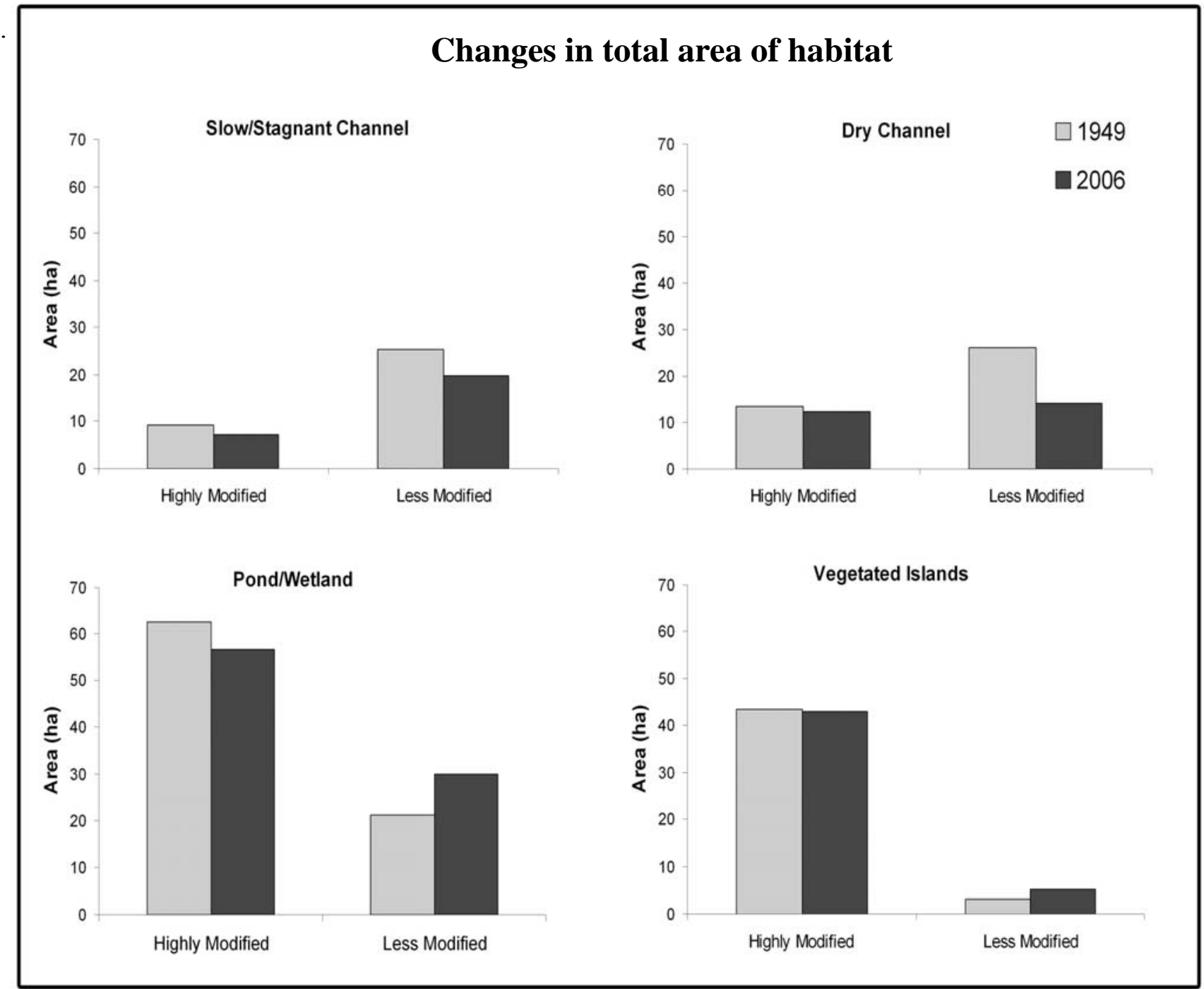




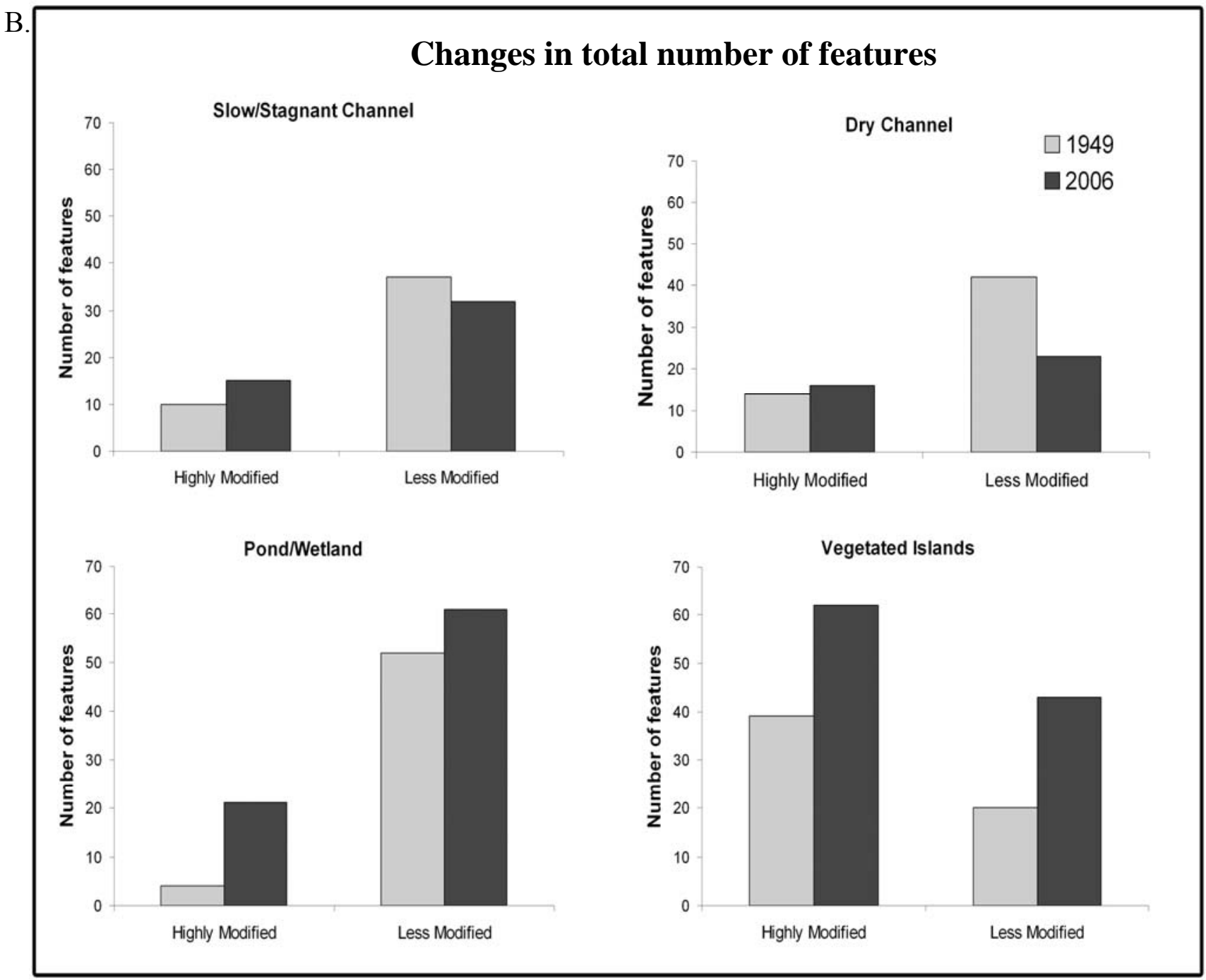




\section{Literature Cited}

Abbe, T. B. and D. R. Montgomery. 2003. Patterns and processes of wood debris accumulation in the Queets river basin, Washington. Geomorphology 51:81-107.

Andonaegui, C. 2001. Salmon, Steelhead, and Bull Trout Habitat Limiting Factors For the Wenatchee Subbasin (Water Resource Inventory Area 45) and Portions of WRIA 40 within Chelan County (Squilchuck, Stemilt and Colockum drainages). WA State Conservation Commission, Olympia, WA.

Beechie, T. J., B.D. Collins, and G. R. Pess. 2001. Holocene and Recent Geomorphic Processes, Land Use and Salmonid Habitat in Two North Puget Sound River Basins. . Pages 37-54 in J. B. Dorava, D. R. Montgomery, F. Fitzpatrick, and B. Palcsak, editors. Geomorphic processes and riverine habitat. American Geophysical Union, Washington, D.C.

Beechie, T. J., E. Beamer, and L. Wasserman. 1994. Estimating Coho Salmon Rearing Habitat and Smolt Production Losses in a Large River Basin, and Implications for Habitat Restoration. North American Journal of Fisheries Management 14:797-811.

Beechie, T. J., M. Liermann, M. M. Pollock, S. Baker, and J. Davies. 2006. Channel pattern and river-floodplain dynamics in forested mountain river systems. Geomorphology 78:124-141.

Bjornn, T. and D. Reisser. 1991. Habitat requirements of salmonids in streams. Pages 83-138 in W. Meehan, editor. Influences of Forest and Rangeland Management on Salmonid Fisheries and Their Habitats. American Fisheries Society Special Publication, Bethesda, Maryland.

Brown, T. G. and G. F. Hartman. 1988. Contribution of Seasonally Flooded Lands and Minor Tributaries to the Production of Coho Salmon in Carnation Creek, British Columbia. Transactions of the American Fisheries Society 117:546-551.

Bugert, R. M., T. C. Bjornn, and W. R. Meehan. 1991. Summer Habitat Use by Young Salmonids and Their Responses to Cover and Predators in a Small Southeast Alaska Stream. Transactions of the American Fisheries Society 120:474-485.

Chapman, D., C. Peven, A. Giorgi, T. Hillman, and F. Utter. 1995. Status of spring chinook salmon in the mid-Columbia River. Don Chapman Consultants, Boise, ID.

Collins, B. D., D. R. Montgomery, and A. D. Haas. 2002. Historical changes in the distribution and functions of large wood in Puget Lowland rivers. Canadian Journal of Fisheries and Aquatic Sciences 59:66-76. 
DFO. 2005. Canada's policy for conservation of wild Pacific salmon., Vancouver, British Columbia.

Fausch, K. D. and T. G. Northcote. 1992. Large Woody Debris and Salmonid Habitat in a Small Coastal British-Columbia Stream. Canadian Journal of Fisheries and Aquatic Sciences 49:682-693.

Ford, M., P. Budy, C. Busack, D. Chapman, T. Cooney, T. Fisher, J. Geiselman, T. Hillman, J. Lukas, C. Peven, C. Toole, E. Weber, and P. Wilson. 2001. Upper Columbia River Steelhead and Spring Chinook Salmon Population Structure and Biological Requirements. Upper Columbia River Steelhead and Spring Chinook Salmon Biological Requirements Committee, Seattle, WA.

Gergel, S. E., M. G. Turner, J. R. Miller, J. M. Melack, and E. H. Stanley. 2002. Landscape indicators of human impacts to riverine systems. Aquatic Sciences 64:118-128.

Gregory, S. V., F. J. Swanson, W. A. Mckee, and K. W. Cummins. 1991. An Ecosystem Perspective of Riparian Zones. Bioscience 41:540-551.

Gurnell, A., K. Tockner, P. Edwards, and G. Petts. 2005. Effects of deposited wood on biocomplexity of river corridors. Frontiers in Ecology and the Environment 3:377382.

Hall, J. E., D. M. Holzer, and T. J. Beechie. 2007. Predicting river floodplain and lateral channel migration for salmon habitat conservation. Journal of the American Water Resources Association 43:786-797.

Harding, J. S., E. F. Benfield, P. V. Bolstad, G. S. Helfman, and E. B. D. Jones. 1998. Stream biodiversity: The ghost of land use past. Proceedings of the National Academy of Sciences of the United States of America 95:14843-14847.

Hicks, B. J., J. D. Hall, P. A. Bisson, and J. R. Sedell. 1991. Responses of salmonids to habitat changes. Pages 483-518 in W. Meehan, editor. Influences of Forest and Rangeland Management on Salmonid Fisheries and Their Habitats. American Fisheries Society Special Publication, Bethesda, Maryland.

Hohensinner, S., H. Habersack, M. Jungwirth, and G. Zauner. 2004. Reconstruction of the characteristics of a natural alluvial river-floodplain system and hydromorphological changes following human modifications: The Danube River (1812-1991). River Research and Applications 20:25-41.

Honea, J. M., J. C. Jorgensen, M. M. McClure, T. D. Cooney, K. Engie, D. M. Holzer, and R. Hilborn. 2009. Evaluating habitat effects on population status: influence of habitat restoration on spring-run Chinook salmon. Freshwater Biology 54:1576-1592. 
ICTRT. 2003. Independent populations of Chinook, and steelhead and sockeye for listed evolutionarily significant units within the interior Columbia River Basin domain., National Oceanic and Atmospheric Administration, National Marine Fisheries Service, Northwest Fisheries Science Center, Seattle.

ICTRT. 2007. Viability Criteria for Application to Interior Columbia Basin Salmonid ESUs. National Oceanic and Atmospheric Administration, National Marine Fisheries Service, Northwest Fisheries Science Center, Seattle.

Innis, S. A., R. J. Naiman, and S. R. Elliott. 2000. Indicators and assessment methods for measuring the ecological integrity of semi-aquatic terrestrial environments. Hydrobiologia 422:111-131.

Jeffres, C. A., J. J. Opperman, and P. B. Moyle. 2008. Ephemeral floodplain habitats provide best growth conditions for juvenile Chinook salmon in a California river. Environmental Biology of Fishes 83:449-458.

Jorgensen, J. C., J. M. Honea, M. M. McClure, T. D. Cooney, K. Engie, and D. M. Holzer. 2009. Linking landscape-level change to habitat quality: an evaluation of restoration actions on the freshwater habitat of spring-run Chinook salmon. Freshwater Biology 54:1560-1575.

Jungwirth, M., S. Muhar, and S. Schmutz. 2002. Re-establishing and assessing ecological integrity in riverine landscapes. Freshwater Biology 47:867-887.

Lindborg, R. and O. Eriksson. 2004. Historical landscape connectivity affects present plant species diversity. Ecology 85:1840-1845.

Lunetta, R. S., B. L. Cosentino, D. R. Montgomery, E. M. Beamer, and T. J. Beechie. 1997. GIS-based evaluation of salmon habitat in the Pacific Northwest. Photogrammetric Engineering and Remote Sensing 63:1219-1229.

Lyons, J., L. Wang, and T. D. Simonson. 1996. Development and Validation of an Index of Biotic Integrity for Coldwater Streams in Wisconsin. North American Journal of Fisheries Management 16:241-256.

Meehan, W. R., F. J. Swanson, and J. R. Sedell. 1977. Influences of riparian vegetation on aquatic ecosystems with particular reference to salmonid fishes and their food supply. USDA Forest Service General Technical Report RM-43, Tuscon, Arizona.

Montgomery, D. R. 1999. Process domains and the river continuum. Journal of the American Water Resources Association 35:397-410.

Montgomery, D. R. and J. M. Buffington. 1997. Channel-reach morphology in mountain drainage basins. Geological Society of America Bulletin 109:596-611. 
Murphy, M. L. and W. Meehan. 1991. Stream Ecosystems. Pages 17-46 in W. Meehan, editor. Influences of Forest and Rangeland Management on Salmonid Fisheries and Their Habitats. American Fisheries Society Special Publication, Bethesda, Maryland.

Myers, J. M., R. G. Kope, G. J. Bryant, D. Teel, L. J. Lierheimer, T. C. Wainwright, W. S. Grant, F. W. Waknitz, K. Neely, S. T. Lindley, and R. S. Waples. 1998. Status review of chinook salmon from Washington, Idaho, Oregon, and California., U.S. Department of Commerce.

Naiman, R. J., R. E. Bilby, and P. A. Bisson. 2000. Riparian ecology and management in the Pacific Coastal Rain Forest. Bioscience 50:996-1011.

Nehlsen, W., J. E. Williams, and J. A. Lichatowich. 1991. Pacific Salmon at the Crossroads Stocks at Risk from California, Oregon, Idaho, and Washington. Fisheries 16:4-21.

NRC. 1996. Upstream : salmon and society in the Pacific Northwest. National Academy Press, Washington, D.C.

Pollock, M. M. 1998. Biodiversity. Pages 430-452 in R. J. Naiman and R. E. Bilby, editors. River ecology and management : lessons from the Pacific coastal ecoregion. Springer, New York.

Poudevigne, I. and J. Baudry. 2003. The implication of past and present landscape patterns for biodiversity research: introduction and overview. Landscape Ecology 18:223-225.

Roth, N. E., J. D. Allan, and D. L. Erickson. 1996. Landscape influences on stream biotic integrity assessed at multiple spatial scales. Landscape Ecology 11:141-156.

Schindler, D. E., M. D. Scheuerell, J. W. Moore, S. M. Gende, T. B. Francis, and W. J. Palen. 2003. Pacific salmon and the ecology of coastal ecosystems. Frontiers in Ecology and the Environment 1:31-37.

Schulte, L. A., D. J. Mladenoff, and E. V. Nordheim. 2002. Quantitative classification of a historic northern Wisconsin (USA) landscape: mapping forests at regional scales. Canadian Journal of Forest Research-Revue Canadienne De Recherche Forestiere 32:1616-1638.

Simonson, T. D., J. Lyons, and P. Kanehl. 1993. Guidelines for evaluating fish habitat in Wisconsin streams. U.S. Dept. of Agriculture, Forest Service, North Central Forest Experiment Station, St. Paul, MN.

Sommer, T. R., M. L. Nobriga, W. C. Harrell, W. Batham, and W. J. Kimmerer. 2001. Floodplain rearing of juvenile chinook salmon: evidence of enhanced growth and survival. Canadian Journal of Fisheries and Aquatic Sciences 58:325-333. 
Sponseller, R. A., E. F. Benfield, and H. M. Valett. 2001. Relationships between land use, spatial scale and stream macroinvertebrate communities. Freshwater Biology

46:1409-1424.

Stewart, G. B., H. R. Bayliss, D. A. Showler, W. J. Sutherland, and A. S. Pullin. 2009. Effectiveness of engineered in-stream structure mitigation measures to increase salmonid abundance: a systematic review. Ecological Applications 19:931-941.

Thompson, D. M. 2006. Did the pre-1980 use of in-stream structures improve streams? A reanalysis of historical data. Ecological Applications 16:784-796.

Vitousek, P. M., H. A. Mooney, J. Lubchenco, and J. M. Melillo. 1997. Human domination of Earth's ecosystems. Science 277:494-499.

Wang, L. Z., J. Lyons, P. Kanehl, and R. Gatti. 1997. Influences of watershed land use on habitat quality and biotic integrity in Wisconsin streams. Fisheries 22:6-12.

Ward, J. V., K. Tockner, D. B. Arscott, and C. Claret. 2002. Riverine landscape diversity. Freshwater Biology 47:517-539.

White, M. D. and K. A. Greer. 2006. The effects of watershed urbanization on the stream hydrology and riparian vegetation of Los Penasquitos Creek, California. Landscape and Urban Planning 74:125-138.

Young, K. A. 2001. Habitat diversity and species diversity: testing the competition hypothesis with juvenile salmonids. Oikos 95:87-93.

Zanoni, L., A. Gurnell, N. Drake, and N. Surian. 2008. Island Dynamics in a Braided River from Analysis of Historical Maps and Air Photographs. River Research and Applications 24:1141-1159. 


\section{CONCLUSION}

\section{Conclusions and Implications}

Salmonids are imperiled throughout much of their historic range, not just in the Wenatchee River watershed (Nehlsen et al. 1991, Myers et al. 1998, Schindler et al. 2003). Fish species worldwide are experiencing population declines (Nehlsen et al. 1991, Vitousek et al. 1997); much of these losses in diversity can be attributed to anthropogenic habitat alteration (Nehlsen et al. 1991, Jungwirth et al. 2002). The research presented here allowed for the quantification of broad-scale, landscape level changes in habitat. Historic agricultural and modern urban land cover can negatively impact salmonid habitat quality (Wang et al. 1997, Harding et al. 1998). Thus, large historic abundances of agriculture and subsequent conversion to urban uses have likely reduced salmonid habitat quality in the Wenatchee system. Island braided and meandering reach types are likely to contain high quality salmonid habitat (Beechie et al. 2006, Zanoni et al. 2008); thus, loss of these reach types have likely decreased the high quality in-stream and off-channel habitat available to salmonids in the study area.

The increase in anthropogenic floodplain modification and decline in meandering channels likely reduced the potential of streams to develop off-channel habitat. Slow/stagnant and dry channels have declined in the Wenatchee system, further reducing the availability of valuable salmonid habitat. Furthermore, increased habitat fragmentation, particularly in highly modified floodplains, may have also made remaining floodplain habitats less accessible to salmonids. Reestablishment of channel migration helps create a self-sustaining mechanism 
for river restoration that can lead to long-term improvements in stream habitat (Ward et al. 2002). Furthermore, fish population recovery can benefit from restoration of floodplain habitat (Beechie et al. 1994, Sommer et al. 2001, Jeffres et al. 2008).

Straight channel types and urban land cover are both highly persistent and increasing in dominance within the study area. The combination of these two factors will likely result in further river-floodplain degradation in the absence of any active conservation, restoration or management plans. Furthermore, simply due to mapping error, it is likely that the historic abundance of straight reaches was overestimated, and that the original abundance of island braided reaches was underestimated. Consequently, even more island braided reaches may have been lost than reported here, and the likelihood of stream straightening reported may actually be an underestimate. The increasing dominance and persistence of lower quality reach types in the Wenatchee system (from the prospective of salmonids) is of tremendous management concern.

\section{Applications for Management}

Detailed high resolution information regarding historic landscape conditions are of paramount importance for fish management plans. Maps of the historic extent of land cover, stream reach type and floodplain and channel habitat will help provide the necessary information needed to reconstruct the original abundance and location of salmonid habitat in the Wenatchee system. As the Wenatchee system was once prime spawning habitat for salmonids (Andonaegui 2001, Honea et al. 2009), there is a high potential for habitat restoration. Reconstructing the historic river floodplain of the Wenatchee system and 
subsequent losses of habitat can help locate specific areas of prime historic habitat; comparison with modern imagery helps determine current status of such areas. The identification of historic areas of high quality floodplain habitat, productive stream reach types and optimal riparian structure precisely locate where salmonid spawning areas may have been the most productive. Thus, these particular locations are likely prime candidates for restoration planning guided by the results of this historic reconstruction. Finally, the results of this study not only identify areas for habitat restoration, they also identify prime salmonid habitat that has remained intact. Such areas should given priority for habitat conservation. For example, streams approaching the meandering-straight sinuosity threshold $($ sinuosity $=1.5)$ have a greater potential to straighten, representing a loss in high quality habitat and should be denoted for protection.

Managers will be able to use this historic dataset to model how loss of floodplain, riparian and channel habitat has influenced salmonid population declines relative to other factors. Previous studies attempting such models have sited lack of historic data for habitat features as a limiting factor in their analyses (Beechie et al. 1994, Jorgensen et al. 2009). This research provides historic information that can be used to estimate intrinsic habitat potential, a framework used to guide management (ICTRT 2007). Non-habitat related information exists for the Wenatchee basin (e.g., population, geopolitical, transportation, etc.), which can provide a more complete picture of other important drivers of salmonid population declines (see Honea et al. (2009) or Jorgensen et al. (2009) for examples). Finally, the general methodology used in this study may be adapted to other rivers throughout Canada and the 
USA where salmonid populations are in decline (e.g., the Fraser River (CA) and the Snake River (USA).

\section{Future Research}

A significant amount of time was needed for the preparation of the historic orthomosaic of the Wenatchee system. Now that this historic perspective has been created, a number of other historical landscape-level indicators could be derived for a variety of purposes. Distinguishing between coniferous and deciduous forest could be of great benefit as their relative impact on dynamics of stream ecosystems have been well documented (Bilby and Bisson 1998, Naiman et al. 2000, Gurnell et al. 2002, Gregory et al. 2003). Conifers are more resistant to decay and tend to be larger in diameter than most deciduous species. Therefore, conifers persist longer in streams and are not dislodged as easily by stream discharge or torrent events (Naiman et al. 2000). While deciduous trees tend to be smaller in diameter and decay quicker in streams (Naiman et al. 2000), they do provide other ecosystem services (e.g., regulate stream temperature or nutrient input; Gregory et al. 1991). As large wood is an integral part of a healthy stream ecosystem, historic data on coniferous and deciduous forest structure surrounding streams could be of great benefit to managers. In fact, lack of historical data on large wood in channels was a reported limitation of a recovery model developed for Chinook salmon in the Wenatchee basin (Honea et al. 2009).

Other proxies or indicators of stream condition could be quantified from the historic orthoimagery. Temperature can be a limiting factor for fish populations in streams (Bjornn and Reisser 1991, Hicks et al. 1991), and may be of special concern in light of projected 
future climate change. Streams with dense riparian vegetation receive less direct sunlight and would therefore maintain more stable stream temperatures as opposed to streams with sparse or absent riparian vegetation that receive ample solar radiation (Gregory et al. 1991, Hicks et al. 1991, Murphy and Meehan 1991). Mapping of riparian structure (tree species, age or height as well as canopy density) could be combined with stream width information to develop a stream shading index. Such an index could be used to estimate the amount and location of shaded stream segments and serve as a proxy for how well a stream may be buffered against temperature extremes.

Sedimentation is also a major factor affecting salmonids, most notably during egg incubation (Bjornn and Reisser 1991, Hicks et al. 1991). Upland land use practices (e.g., timber harvest or yarding activities), percent riparian forested area and road density have been used as indicators of potential sedimentation over time (Bjornn and Reisser 1991, Hicks et al. 1991). For example, unpaved, actively-used logging roads can produce fine sediment loading to a stream equal to that produced by a landslide (Reid and Dunne 1984). Upland agricultural land use has also been shown to increase sedimentation in stream channels (Lenat 1984, Richards et al. 1996). Therefore, a land cover map covering a broader extent (beyond the floodplain boundary) and a more detailed road layer (distinguishing paved vs. unpaved roads) would be logical next steps in quantifying the location of potential sedimentation risks throughout the watershed. Forest fires can also increase fine sediment loading to streams (Meyer et al. 1992, Meyer and Wells 1997). The location, size and severity of historic fires could be reconstructed. Fire severity can be inferred from detailed photo interpretation of forest structure; such methods have been developed specifically for the Wenatchee watershed 
(Hessburg et al. 2007). Knowledge of fire patterns could be helpful in understanding watershed-level sedimentation budgets.

The indicators used in this study provide initial possibilities for historic reconstruction in this region. Many additional questions elucidating the nature of historic terrestrial-aquatic interactions could be answered with the tools and datasets explored here. This study quantified several anthropogenic pressures influencing the Wenatchee system in the past and present and developed methods to infer how these pressures may have affected salmonid habitat. Developing datasets that describe riparian structure, as well as indicators of stream temperature and sedimentation, could create a far richer dataset useful in quantifying how changes in the landscape affect stream condition at different spatial scales. Linking these proxies of habitat condition to salmonid population data creates a powerful spatially explicit model capable of teasing apart the relative importance of historic changes in habitat and how they have influenced current salmonid populations relative to other causes of decline. A model such as this would be invaluable not only to understanding how human behavior has affected population declines, but also in forecasting how current human actions might impact future salmonid stocks. 


\section{Literature Cited}

Andonaegui, C. 2001. Salmon, Steelhead, and Bull Trout Habitat Limiting Factors For the Wenatchee Subbasin (Water Resource Inventory Area 45) and Portions of WRIA 40 within Chelan County (Squilchuck, Stemilt and Colockum drainages). WA State Conservation Commission, Olympia, WA.

Beechie, T. J., E. Beamer, and L. Wasserman. 1994. Estimating Coho Salmon Rearing Habitat and Smolt Production Losses in a Large River Basin, and Implications for Habitat Restoration. North American Journal of Fisheries Management 14:797-811.

Beechie, T. J., M. Liermann, M. M. Pollock, S. Baker, and J. Davies. 2006. Channel pattern and river-floodplain dynamics in forested mountain river systems. Geomorphology 78:124-141.

Bilby, R. E. and P. A. Bisson. 1998. Function and distribution of large woody debris. Pages xxiv, 705 p. in R. J. Naiman and R. E. Bilby, editors. River ecology and management : lessons from the Pacific coastal ecoregion. Springer, New York.

Bjornn, T. and D. Reisser. 1991. Habitat requirements of salmonids in streams. Pages 83-138 in W. Meehan, editor. Influences of Forest and Rangeland Management on Salmonid Fisheries and Their Habitats. American Fisheries Society Special Publication, Bethesda, Maryland.

Gregory, S., K. L. Boyer, and A. M. Gurnell. 2003. The ecology and management of wood in world rivers. American Fisheries Society, Bethesda, Md.

Gregory, S. V., F. J. Swanson, W. A. Mckee, and K. W. Cummins. 1991. An Ecosystem Perspective of Riparian Zones. Bioscience 41:540-551.

Gurnell, A. M., H. Piegay, F. J. Swanson, and S. V. Gregory. 2002. Large wood and fluvial processes. Freshwater Biology 47:601-619.

Harding, J. S., E. F. Benfield, P. V. Bolstad, G. S. Helfman, and E. B. D. Jones. 1998. Stream biodiversity: The ghost of land use past. Proceedings of the National Academy of Sciences of the United States of America 95:14843-14847.

Hessburg, P. F., R. B. Salter, and K. M. James. 2007. Re-examining fire severity relations in pre-management era mixed conifer forests: inferences from landscape patterns of forest structure. Landscape Ecology 22:5-24.

Hicks, B. J., J. D. Hall, P. A. Bisson, and J. R. Sedell. 1991. Responses of salmonids to habitat changes. Pages 483-518 in W. Meehan, editor. Influences of Forest and Rangeland Management on Salmonid Fisheries and Their Habitats. American Fisheries Society Special Publication, Bethesda, Maryland. 
Honea, J. M., J. C. Jorgensen, M. M. McClure, T. D. Cooney, K. Engie, D. M. Holzer, and R. Hilborn. 2009. Evaluating habitat effects on population status: influence of habitat restoration on spring-run Chinook salmon. Freshwater Biology 54:1576-1592.

ICTRT. 2007. Viability Criteria for Application to Interior Columbia Basin Salmonid ESUs. National Oceanic and Atmospheric Administration, National Marine Fisheries Service, Northwest Fisheries Science Center, Seattle.

Jeffres, C. A., J. J. Opperman, and P. B. Moyle. 2008. Ephemeral floodplain habitats provide best growth conditions for juvenile Chinook salmon in a California river. Environmental Biology of Fishes 83:449-458.

Jorgensen, J. C., J. M. Honea, M. M. McClure, T. D. Cooney, K. Engie, and D. M. Holzer. 2009. Linking landscape-level change to habitat quality: an evaluation of restoration actions on the freshwater habitat of spring-run Chinook salmon. Freshwater Biology 54:1560-1575.

Jungwirth, M., S. Muhar, and S. Schmutz. 2002. Re-establishing and assessing ecological integrity in riverine landscapes. Freshwater Biology 47:867-887.

Lenat, D. R. 1984. Agriculture and Stream Water-Quality - a Biological Evaluation of Erosion Control Practices. Environmental Management 8:333-343.

Meyer, G. A. and S. G. Wells. 1997. Fire-related sedimentation events on alluvial fans, Yellowstone National Park, USA. Journal of Sedimentary Research 67:776-791.

Meyer, G. A., S. G. Wells, R. C. Balling, and A. J. T. Jull. 1992. Response of Alluvial Systems to Fire and Climate Change in Yellowstone-National-Park. Nature 357:147150.

Murphy, M. L. and W. Meehan. 1991. Stream Ecosystems. Pages 17-46 in W. Meehan, editor. Influences of Forest and Rangeland Management on Salmonid Fisheries and Their Habitats. American Fisheries Society Special Publication, Bethesda, Maryland.

Myers, J. M., R. G. Kope, G. J. Bryant, D. Teel, L. J. Lierheimer, T. C. Wainwright, W. S. Grant, F. W. Waknitz, K. Neely, S. T. Lindley, and R. S. Waples. 1998. Status review of chinook salmon from Washington, Idaho, Oregon, and California., U.S. Department of Commerce.

Naiman, R. J., R. E. Bilby, and P. A. Bisson. 2000. Riparian ecology and management in the Pacific Coastal Rain Forest. Bioscience 50:996-1011.

Nehlsen, W., J. E. Williams, and J. A. Lichatowich. 1991. Pacific Salmon at the Crossroads Stocks at Risk from California, Oregon, Idaho, and Washington. Fisheries 16:4-21. 
Reid, L. M. and T. Dunne. 1984. Sediment Production from Forest Road Surfaces. Water Resources Research 20:1753-1761.

Richards, C., L. B. Johnson, and G. E. Host. 1996. Landscape-scale influences on stream habitats and biota. Canadian Journal of Fisheries and Aquatic Sciences 53:295-311.

Schindler, D. E., M. D. Scheuerell, J. W. Moore, S. M. Gende, T. B. Francis, and W. J. Palen. 2003. Pacific salmon and the ecology of coastal ecosystems. Frontiers in Ecology and the Environment 1:31-37.

Sommer, T. R., M. L. Nobriga, W. C. Harrell, W. Batham, and W. J. Kimmerer. 2001. Floodplain rearing of juvenile chinook salmon: evidence of enhanced growth and survival. Canadian Journal of Fisheries and Aquatic Sciences 58:325-333.

Vitousek, P. M., H. A. Mooney, J. Lubchenco, and J. M. Melillo. 1997. Human domination of Earth's ecosystems. Science 277:494-499.

Wang, L. Z., J. Lyons, P. Kanehl, and R. Gatti. 1997. Influences of watershed land use on habitat quality and biotic integrity in Wisconsin streams. Fisheries 22:6-12.

Ward, J. V., K. Tockner, D. B. Arscott, and C. Claret. 2002. Riverine landscape diversity. Freshwater Biology 47:517-539.

Zanoni, L., A. Gurnell, N. Drake, and N. Surian. 2008. Island Dynamics in a Braided River from Analysis of Historical Maps and Air Photographs. River Research and Applications 24:1141-1159. 


\section{APPENDIX I}

\section{Orthorectification of Aerial Photographs}

The historic data used in this study was collected from a mosaic of historic aerial photographs (circa 1949). The airphotos were first orthorectified before any measurements were taken. As an aerial photograph is captured, a number of distortions or degradations (e.g., relief/tilt distortion or radial displacement) are manifested in the resultant image. Orthorectification is the process of correcting these errors and creating an orthophoto that is free of distortions and has a constant scale. The resultant image is considered to be planimetrically correct. After the image has been rectified, it can then be used to extract accurate distances, calculate areal measurements, record direction or relate data in a geographic information system (GIS).

Two types of errors generated in the process of generating aerial photographs are systematic (predictable) and nonsystematic (random) errors. Systematic errors are easier to correct and result from a variety of known phenomena, (e.g., the eastward rotation of the Earth or offnadir pixel capture); in satellite imagery, most of these errors are corrected by the image distributor. Random errors are more difficult to correct and generally result from movement of the sensor at the time of image capture (primarily altitude and attitude changes). To correct for random errors, the raw aerial photograph must undergo two orientation processes (interior and exterior). Orientation is based on the photogrammetric property of collinearity which states that for any object on the ground, its point on the photo image and the photographic plane all lie in a straight line (Wolf and Dewitt 2000). In interior orientation, 
the camera geometry is recalculated at the moment of image capture (Wolf and Dewitt 2000) by inputting the camera's focal length and measurements of the boundaries of the photograph by registering fiducial marks. In exterior orientation (or spatial resectioning), a mathematical algorithm relates the physical location and angle of reflectance for the image effectively calculating the sensor's geometry (Lillesand et al. 2004). Exterior orientation is accomplished in two steps: mathematical transformation and image resampling.

Mathematical transformation is the process of relating an uncorrected (raw) image to a reference file such as a map of vector data (image-to-map rectification) or a corrected image (image-to-image rectification). In either case, a series of identical points between the uncorrected image and the reference file, known as ground control points (GCPs), are identified. While GCPs should be evenly distributed across the image and have distinguishable locations, increased accuracy in measurements derived from the orthoimage can be achieved by concentrating additional GCPs in the of areas of interest (Hughes et al. 2006). For example, if the focus of a study is within a river corridor, then GCPs should be distributed across the entire photo (e.g., the watershed), but additional GCPs should be placed in the river corridor increasing positional accuracy in the area of interest.

The collection of GCPs allows the software to relate column and row data from the image (i.e., individual pixels) to map coordinates in the reference file (lat/long or meters as in UTM). The more (accurate) GCPs collected, the stronger the relationship between the image and reference file, yielding a more accurate orthoimage (Hughes et al. 2006). The accuracy of the transformation equation is related to the topography of the imaged area (mountainous 
regions are more difficult to correct than flat regions), the number of GCPs collected and the overall distortion of the image. To correct for radial displacement due to topography, height must be factored into the rectification through the use of a digital elevation model (DEM). Elevation data from a joined DEM is collected simultaneously with the GCPs. The software uses the GCPs to calculate a least-squares regression resulting in a transformation equation which converts the remaining image pixels to map coordinates. A result of this process is the root-mean-squared error (RMSE) term. An RMSE for the equation is calculated and estimates the overall error around the regression equation. An RMSE for each GCP is also calculated and estimates the variation in the GCP around the regression equation. The more complicated the original image, the more complicated the subsequent transformation equation will be. Simple models can use linear equations; more complex models use higherorder polynomial equations.

The transformation equation calculates the new grid location for each pixel; therefore, the final step in creating the output (corrected) image is to assign a digital number (DN) to the new grid location. Unfortunately, there is rarely an occasion when the initial pixel value lines up perfectly with the new grid. In these instances, a mechanism for calculating the new DN for the new grid is necessary (i.e., spatial interpolation). There are a myriad of interpolation methods, but the three most common are nearest neighbor, bilinear and cubic convolution. Nearest neighbor resamples on the basis of proximity; the output grid cell receives the DN value from the closest pixel in the original image. Even though this method offers computational simplicity and maintains the original $\mathrm{DN}$ values, it can produce output images that appear disjointed (Lillesand et al. 2004). Bilinear interpolation and cubic 
convolution operate on the same principle, the output $\mathrm{DN}$ value is a distance-weighted average of either the four or 16 closest pixels from the original image respectively. As both bilinear and cubic convolution result in synthetic DN values, post-classification resampling should be considered. 


\section{Literature Cited}

Hughes, M. L., P. F. McDowell, and W. A. Marcus. 2006. Accuracy assessment of georectified aerial photographs: Implications for measuring lateral channel movement in a GIS. Geomorphology 74:1-16.

Jorgensen, J. C., J. M. Honea, M. M. McClure, T. D. Cooney, K. Engie, and D. M. Holzer. 2009. Linking landscape-level change to habitat quality: an evaluation of restoration actions on the freshwater habitat of spring-run Chinook salmon. Freshwater Biology 54:1560-1575.

Lillesand, T. M., R. W. Kiefer, and J. W. Chipman. 2004. Remote sensing and image interpretation. 5th edition. Wiley, New York.

Wolf, P. R. and B. A. Dewitt. 2000. Elements of photogrammetry : with applications in GIS. 3rd edition. McGraw-Hill, Boston. 